\title{
STRUCTURE AND SUBSTITUTIONS IN FLUORAPATITE
}

\author{
N. Leroy* and E. Bres \\ CNRS ESA 8008 - LSPES - USTL, Villeneuve d'Ascq, France
}

\begin{abstract}
Fluorapatite, $\mathrm{Ca}_{10}\left(\mathrm{PO}_{4}\right)_{6} \mathrm{~F}_{2}$. is a widely spread form of calcium phosphate present particularly in biological material. Human hard tissues contain crystals structurally related to apatite. Fluoride can be found in various natural sources and is also used for its beneficial action in caries prevention. Fluorapatite belongs to the spatial group $P_{6} / m\left(C_{6 h}{ }^{2}\right)$ and consists of 3 ions: $\mathrm{F}^{-}, \mathrm{Ca}^{2+}, \mathrm{PO}_{4}^{3-}$. In the present paper, we have carried out a crystallographic study of the fluorapatite structure and of the changes induced by the substitutions. The fluorapatite structure and the presence of a large number of ionic bonds make fluorapatite a very suitable host for many substitutents, some of them harmless for the human organism, some not. According to the substitution site, we can describe four types of substitution. The F- substitution, also called Type A substitution, is the main one, and the best known. Only the $\mathrm{Ca}^{2+}$ substitution implies changes in the crystal structure. However, some questions remain, in particular for the $\mathrm{PO}_{4}^{3-}$ substitution, which is the main substitution present in the biological calcium phosphates.
\end{abstract}

Key Words: Apatite structure, space group, point group, substitution, fluoride.

*Address for correspondence:

N. Leroy

CNRS ESA 8008 - LSPES - USTL Bâtiment C6 - F-59655

VIlleneuve d'Ascq Cedex, France

Telephone Number: (33) 3.20.43.69.66

Fax Number: (33) 3.20.43.65.91

E-mail : Nathalie.Leroy@univ-lille1.fr

\section{Introduction}

The main components of the apatite family are hydroxyapatite $\left(\mathrm{OHAp}, \mathrm{Ca}_{10}\left(\mathrm{PO}_{4}\right)_{6}(\mathrm{OH})_{2}\right)$, chlorapatite (ClAp, $\left.\mathrm{Ca}_{10}\left(\mathrm{PO}_{4}\right)_{6} \mathrm{Cl}_{2}\right)$, carbonated apatites and fluorapatite (FAp, $\mathrm{Ca}_{10}\left(\mathrm{PO}_{4}\right)_{6} \mathrm{~F}_{2}$ ). For the latter component, several applications in different areas are known. The existence of several natural minerals containing this component (e.g., Durango, Mexico; Quebec, Canada; New Mexico or Connecticut, USA; Epirus, Greece) (Bale, 1940; Hendricks et al., 1932; Sudarsanan et al., 1972) has led to their use in many applications. There are several methods for synthesis, which allows control of stoichiometry and/or morphology of the synthesized calcium phosphate (Elliot, 1998). In addition, FAp has been used in phosphorus chemistry, as a catalyser or $\mathrm{a}_{3} \mathrm{PO}_{4}$ source (this represents $75 \%$ of natural apatite use), but also in the area of solid-state laser hosts (rare-earth doped FAp), and in geology as a probe of phosphorus activity in hydrothermal, metamorphic or magmatic processes. FAp is also the main calcium phosphate used in phosphated fertilisers. However, its first industrial use, in a Sb- or Mn-substituted form remains the production of fluorescent lamps (estimated to 10 tons per day in 1991) (DeBoer et al., 1991; Fleet and Pan, 1997; Hughes et al., 1991; Miyake et al., 1986; Suitch et al., 1985). Calcium apatites are also important in biology, because they form the mineral part of bone and teeth, and take part in the mineralization process. FAps are used as biocompatible materials for bone replacement and coating of bone prostheses.

One of the components of FAp is fluoride, which is often used therapeutically in order to prevent caries. In nature, fluoride can be found in soils, in minerals such as fluorine, hornblende, pegmatite, and FA. Due to erosion, fluoride salts are also present in the atmosphere. The atmospheric concentration of fluoride salts depends on the presence of fluoride in the environment. Therefore, it is a function of the presence of fluoride in soils or in industrial waste. Fluoride is also present in water, especially in the oceans, or near mountainous or sedimentary areas. Water is also used as a medium of caries prevention politics, and so represents the main source of fluoride in our alimentation. We also can find natural fluoride in some foods, especially in plants, at different concentrations independent of the soil concentration (Plouvier, 1997). All fluoride ingested is first taken up by the circulation, and then in hard tissues (such as bone or dentin). The fixation of fluoride by bone and tooth depends on the supply of fluoride and the age of the subject. Bone is responsible for the homeostasis of fluoride in the organism. Fluoride is excreted by the kidneys, via a passive diffusion mechanism. 
This excretion represents 40 to $60 \%$ of the fluoride ingested.

Fluoride plays an important role in caries prevention: it increases the resistance of the mineral to acid dissolution, and decreases mineral solubility (Aoba, 1997; Featherstone, 1994). By substituting for the $\mathrm{OH}^{-}$ion in the apatite molecule during the development phase of dentin and enamel, fluoride fixes calcium, provides increased stability to the mineral structure, and promotes remineralization (Aoba 1997; Ingram, 1990; Triller 1998).

Moreover, FAp is a suitable host for various substituents that could modify its physicochemical and/ or biological properties. Most of these substituents are harmless, and sometimes necessary for the organism, but some of them could be very dangerous; they could be toxic or cause irreversible modifications of FAp.

All these applications promote scientific interest in this compound. FAp is one of the first apatites of which the structure was described (Mehmel, 1932; Naray-Szabo, 1930), and is considered as a reference model to describe other apatites (Elliot, 1994).

The FAp space group $P 6_{3} / m$ (or $C_{6 h}^{2}$ in the Schöenflies notation) describes the general atomic positions inside its unit cell according to the S.I. and hence permits the construction of the position of the atoms of the unit-cell starting from four ions only: $\mathrm{F}^{-}, \mathrm{Ca}_{\mathrm{I}}{ }^{2+}, \mathrm{Ca}_{\mathrm{II}}{ }^{2+}$ and $\mathrm{PO}_{4}{ }^{3-}$. The knowledge of such symmetries is not only useful for understanding the very structure of FAp but also for the detection of apatite phases and of the structural modifications induced by substitutions and hence for the understanding of the behaviour of biological and synthetic calcium phases. In the present paper, we have carried out a graphical construction of all the atoms of the FAp unit-cell using the symmetry operators of the $P 6_{3} / m$ space group.

\section{Crystallographic Data}

The FAp ionic crystal belongs to the space group $P 6_{3} / m$ ( $C_{6 h}{ }^{2}$ in the Schöenflies notation), and its parameters are $a=b=9.462 \AA$ and $c=6.849 \AA, a=b=90^{\circ}, g=120^{\circ}$ (Hughes et al., 1989). The main symmetry elements are (Naray-Szabo, 1930):

\begin{tabular}{lcccc}
\hline Atom & Symmetry site & \multicolumn{3}{c}{ Crystallographic data } \\
\hline $\mathbf{F}$ & $\overline{6}\left(C_{3 h}\right)$ & 0 & 0 & $1 / 4$ \\
$\mathbf{C a}(\mathbf{I})$ & $3\left(C_{3}\right)$ & $1 / 3$ & $2 / 3$ & 0.00010 \\
$\mathbf{C a}(\mathrm{II})$ & $m\left(C_{s}\right)$ & -0.0071 & 0.2423 & $1 / 4$ \\
$\mathbf{P}$ & $m\left(C_{s}\right)$ & 0.3690 & 0.3985 & $1 / 4$ \\
$\mathbf{O}(\mathbf{I})$ & $m\left(C_{s}\right)$ & 0.4849 & 0.3273 & $1 / 4$ \\
$\mathbf{O}($ II) & $m\left(C_{s}\right)$ & 0.4667 & 0.5875 & $1 / 4$ \\
$\mathbf{O}($ III) & $l(E)$ & 0.2575 & 0.3421 & 0.0705 \\
\hline
\end{tabular}

Table 1: Positions of non-equivalent atoms of FAp. (Hughes et al. 1989).

- A mirror plane, perpendicular to the $c$-axis, at $\mathrm{z}=1 / 4$, - A screw axis $\sigma_{3}$ at the unit-cell origin, parallel to the $c$-axis, and associated with an inversion centre at $(0 ; 0 ; 0)$,

- Three screw axes 2 parallel to the $c$-axis, at the centre of the unit-cell in $(1 / 2 ; 1 / 2 ; z),(1 / 2 ; 0 ; z)$ and $(0 ; 1 / 2 ; \mathrm{z})$. Each axis is associated with an inversion centre $(1 / 2 ; 1 / 2 ; 0),(1 / 2 ; 0 ; 0)$, et $(0 ; 1 / 2 ; 0)$ respectively,

- Two improper rotation axes $\overline{6}$, parallel to the $c$-axis, at $\left(1 / \frac{1}{3} ; 2 / 3 ; \mathrm{z}\right)$ and $(2 / 3 ; 1 / 3 ; \mathrm{z})$.

A FAp unit-cell contains 7 non-equivalent atoms: $\mathrm{F}, \mathrm{Ca}_{\mathrm{I}}$, $\mathrm{Ca}_{\mathrm{II}}, \mathrm{P}, \mathrm{O}(\mathrm{I}), \mathrm{O}_{\mathrm{II}}$ and $\mathrm{O}_{\mathrm{III}}$ (Table 1). To show this property, the FAp chemical formula is written as:

$\mathrm{Ca}(\mathrm{I})_{4} \mathrm{Ca}(\mathrm{II})_{6}\left[\mathrm{PO}(\mathrm{I}) \mathrm{O}(\mathrm{II}) \mathrm{O}(\mathrm{III})_{2}\right]_{6} \mathrm{~F}_{2}$ which takes into account the 4 non-equivalent ions (Table 2):

$$
\begin{array}{ll}
- & \mathrm{F}^{-} \\
- & \mathrm{PO}_{4}^{3-} \\
- & \mathrm{Ca}_{\mathrm{I}}^{2+} \\
- & \mathrm{Ca}_{\mathrm{II}}{ }^{2+}
\end{array}
$$

As Table 1 shows, the atoms are always described by a site symmetry and a single series of coordinates. All other positions can be found with the different symmetry elements. The $\mathrm{O}_{\mathrm{III}}$ atom, which is located at $(0.3416 ; 0.2568 ; 0.0704)$

\begin{tabular}{|c|c|c|c|c|}
\hline Atom & Multiplicity and Wyckoff Symbol & & Crystallographic data & \\
\hline $\mathbf{F}$ & $2 a$ & $(0 ; 0 ; 1 / 4)$ & $(0 ; 0 ; 3 / 4)$ & \\
\hline $\mathbf{C a}(\mathbf{I})$ & $4 f$ & $\left(1 /{ }_{3} ; 2 / 3 ; z\right)$ & $\left(2 /{ }_{3} ; 1 / 3 ; z\right), \quad\left(2 / 3 ; 1 / 3 ; z^{+1 / 2}\right)$ & $(1 / 3 ; 2 / 3 ; 1 / 2-z)$ \\
\hline $\begin{array}{l}\mathrm{Ca}(\mathrm{II}) \\
\mathbf{P} \\
\mathbf{O}(\mathrm{I}) \\
\mathbf{O}(\mathrm{II})\end{array}$ & $6 h$ & $\begin{array}{l}(\mathrm{x} ; \mathrm{y} ; 1 / 4) \\
(1-\mathrm{x} ; 1-\mathrm{y} ; 3 / 4)\end{array}$ & $\begin{array}{ll}(1-\mathrm{y} ; \mathrm{x}-\mathrm{y} ; 1 / 4), & (\mathrm{y}-\mathrm{x} ; 1-\mathrm{x} ; 1 / 4) \\
(\mathrm{y} ; \mathrm{y}-\mathrm{x} ; 3 / 4), & (\mathrm{x}-\mathrm{y} ; \mathrm{x} ; 3 / 4)\end{array}$ & \\
\hline $\mathbf{O}($ III) & $12 i$ & $\begin{array}{l}(x ; y ; z) \\
(1-y ; x-y ; z) \\
(y-x ; 1-x ; z)\end{array}$ & $\begin{array}{ll}(1-\mathrm{x} ; 1-\mathrm{y} ; 1-\mathrm{z}) & (1-\mathrm{x} ; 1-\mathrm{y} ; 1 / 2+\mathrm{z}) \\
(\mathrm{y} ; \mathrm{y}-\mathrm{x} ; 1-\mathrm{z}) & (\mathrm{y} ; \mathrm{y}-\mathrm{x} ; 1 / 2+\mathrm{z}) \\
(\mathrm{x}-\mathrm{y} ; \mathrm{x} ; 1-\mathrm{z}) & (\mathrm{x}-\mathrm{y} ; \mathrm{x} ; 1 / 2+\mathrm{z})\end{array}$ & $\begin{array}{l}(\mathrm{x} ; \mathrm{y} ; 1 / 2-\mathrm{z}) \\
(1-\mathrm{y} ; \mathrm{x}-\mathrm{y} ; 1 / 2-\mathrm{z}) \\
(\mathrm{y}-\mathrm{x} ; 1-\mathrm{x} ; 1 / 2-\mathrm{z})\end{array}$ \\
\hline
\end{tabular}
is in a general position with its site symmetry equal to the identity $1(E)$. All the symmetry operations are used to obtain 12 equivalent points.

Table 2: Site symmetry of FAp atoms in the space group $\mathrm{P} 6_{3} / \mathrm{m}$, according to the International Tables of Crystallography (Hann 1993. Schutte et al. 1997). 


\begin{tabular}{|c|c|c|c|}
\hline Symmetry opération & Unit-Cell & Coordinates & View $[000 \overline{1}]$ \\
\hline \hline$m:$ & & $0.3416 ; 0.2568 ; 0.07704$ \\
mirror symmetry at $z=1 / 4$ \\
$(x ; y ; z) \rightarrow(x ; y ; 1 / 2-z)$
\end{tabular}

Figure 1: Transformations induced by the mirror plane.

\section{Mirror plane}

The mirror plane at $\mathrm{z}=1 / 4$ transforms the initial point to (x ; y ; $1 / 2-\mathrm{z}), i$.e. $(0.3416 ; 0.2568 ; 0.0704)$ to $(0.3416 ; 0.2568 ; 0.4296)$ (Fig. 1$)$.

\section{axis $\overline{\boldsymbol{b}}_{3}$}

The $\sigma_{3}$ axis is located at $(0 ; 0 ; \mathrm{z})$, at the same location as the $c$-axis. The $\mathrm{O}_{\mathrm{III}}$ atom was submitted to a series of operations, consisting of a $2 \mathrm{p} / 6$ rotation and a $3 / 6 c(=1 / 2 c)$ translation. We obtained 6 new points (Fig. 2) :

- $\quad(\mathrm{x}-\mathrm{y} ; \mathrm{x} ; 1 / 2+\mathrm{z}): 0.0848 ; 0.3416 ; 0.5704$

- $\quad(-\mathrm{y} ; \mathrm{x}-\mathrm{y} ; 1+\mathrm{z}):-0.2568 ; 0.0848 ; 1.0704$

- $\quad\left(-\mathrm{x} ;-\mathrm{y} ; 11 \frac{1}{2}+\mathrm{z}\right):-0.3416 ;-0.2568 ; 1.5704$

- $\quad(\mathrm{y}-\mathrm{x} ;-\mathrm{x} ; 2+\mathrm{z}):-0.0848 ;-0.3416 ; 2.0704$

- $\quad\left(\mathrm{y} ; \mathrm{y}-\mathrm{x} ; 2 \frac{1}{2}+\mathrm{z}\right): 0.2568 ;-0.0848 ; 2.5704$

- $\quad(\mathrm{x} ; \mathrm{y} ; 3+\mathrm{z}): 0.3416 ; 0.2568 ; 3.0704$

The inversion point at the origin of the unit-cell transforms these atoms to 6 new points at $\left(-\mathrm{x}^{\prime} ;-\mathrm{y}^{\prime} ;-\mathrm{z}^{\prime}\right)$ :

- $\quad(-0.0848 ;-0.3416 ;-0.5704)$,

- $\quad(0.2568 ;-0.0848 ;-1.0704)$,

- $(0.3416 ; 0.2568 ;-1.5704)$,

- $\quad(0.0848 ; 0.3416 ;-2.0704)$,

- $\quad(-0.2568 ; 0.0848 ;-2.5704)$

- $\quad$ and $(-0.3416 ;-0.2568 ;-3.0704)$

Most of those atoms are outside the FAp unit-cell, but we can find their equivalents inside the unit-cell by lattice translations. So the equivalent positions in the unit-cell are (Fig. 2) :

- $\quad(\mathrm{x} ; \mathrm{y} ; 1 / 2-\mathrm{z}): 0.3416 ; 0.2568 ; 0.4296$

- $\quad(\mathrm{x}-\mathrm{y} ; 1-\mathrm{x} ; 1 / 2-\mathrm{z}): 0.0848 ; 0.6584 ; 0.4296$

- $\quad(1-\mathrm{y} ; \mathrm{x}-\mathrm{y} ; 1 / 2-\mathrm{z}): 0.7432 ; 0.0848 ; 0.4296$

- $\quad(\mathrm{x}-\mathrm{y} ; \mathrm{x} ; 1-\mathrm{z}): 0.0848 ; 0.3416 ; 0.9296$

- $\quad(\mathrm{y} ; 1-\mathrm{x}+\mathrm{y} ; 1-\mathrm{z}): 0.2568 ; 0.9152 ; 0.9296$

- $\quad(1-\mathrm{x} ; 1-\mathrm{y} ; 1-\mathrm{z}): 0.6584 ; 0.7432 ; 0.9296$

\section{$\overline{2}_{1}$ axis}

There are three $2{ }_{1}$ axes, at $(1 / 2 ; 1 / 2 ; z),(1 / 2 ; 0 ; z)$ and $(0 ; 1 / 2 ; z)$. Each axis submits the atoms to a $2 \mathrm{p} / 2$ rotation and a translation of $1 / 2 c$. From the $(\mathrm{x} ; \mathrm{y} ; \mathrm{z})$ coordinates, we obtained 3 points : $(2 * 1 / 2-x ;-y ; 1 / 2+z),(2 * 1 / 2-x ;-y ; 1 / 2+z)$ and $(-\mathrm{x} ; 2 * 1 / 2-\mathrm{y} ; 1 / 2+\mathrm{z})$; i.e. $\left(1-\mathrm{x} ; 1-\mathrm{y} ; \mathrm{z}^{+1 / 2}\right),\left(1-\mathrm{x} ;-\mathrm{y} ; \mathrm{z}^{+1 / 2}\right)$ and $\left(-\mathrm{x} ; 1-\mathrm{y} ; \mathrm{z}^{+1 / 2}\right)$. The succession of these operations gives atoms outside the unit-cell, at $(\mathrm{x} ; \mathrm{y} ; 1+\mathrm{z})$. Moreover, the inversion points at $(1 / 2 ; 1 / 2 ; 0),(1 / 2 ; 0 ; 0)$ and $(0 ; 1 / 2 ; 0)$ transform the coordinates to $\left(1-x^{\prime} ; 1-y^{\prime} ;-z^{\prime}\right)$, $\left(1-x^{\prime} ;-y^{\prime} ;-z^{\prime}\right)$, and (-x';1-y';-z'). Most of the obtained points are outside the unit-cell, but their equivalents can, due to lattice translations, be found within the unit-cell. The new positions of the $\mathrm{O}_{\text {III }}$ atom are (Fig. 3):

$$
\begin{aligned}
& \text { - } \quad \text { axis } \overline{2}_{1} \text { at }(1 / 2 ; 1 / 2 ; \mathrm{z}):(0.3416 ; 0.2568 ;-0.5704) ; \\
& (0.6584 ; 0.7432 ;-1.0704) \\
& \text { - } \quad \text { axis } \overline{2}_{1} \text { at }(1 / 2 ; 1 / 2 ; \mathrm{z}):(0.3416 ; 0.2568 ;-0.5704) ; \\
& (0.6584 ;-0.2568 ;-1.0704) \\
& \text { - } \quad \text { axis } \overline{2}_{1} \text { at }(0 ; 1 / 2 ; \mathrm{z}):(0.3416 ; 0.2568 ;-0.5704) \text {; } \\
& (-0.3416 ; 0.7432 ;-1.0704)
\end{aligned}
$$

In the FAp unit-cell, those positions give two equivalent positions (Fig. 3):

- $\quad(1-\mathrm{x} ; 1-\mathrm{y} ; 1-\mathrm{z}): 0.6584 ; 0.7432 ; 0.9296$

- $\quad$ and $(\mathrm{x} ; \mathrm{y} ; 1 / 2-\mathrm{z}): 0.3416 ; 0.2568 ; 0.4296$

\section{$\operatorname{axis} \overline{6}$}

The unit-cell of the space group $P 6_{3} / m$ has $2 \overline{6}$ axis at $(1 / 3 ; 2 / 3 ; z)$ and $(2 / 3 ; 1 / 3 ; z)$. Each axis is in fact a $2 p / 6$ rotation and an $\mathrm{n}$ inversion. The inversion centres associated with the 6 axis are :

- $\left(1 /{ }_{3} ; 2 / 3 ; 3 / 4\right)$ for the $\left(1 / 3 ;{ }_{3} / 3 ; \mathrm{z}\right)$ axis

- and $\left(2 /{ }_{3} ; 1 / 3 ; 1 / 4\right)$ for the $(2 / 3 ; 1 / 3 ; z)$ axis.

The first $\overline{6}$ axis, at $(1 / 3 ; 2 / 3 ; z)$, gives the following points (Fig. 4):

- $\quad\left(\mathrm{y}-\mathrm{x} ; 1-\mathrm{x} ; 11 \frac{1}{2}-\mathrm{z}\right):-0.0848 ; 0.6584 ; 1.4296$

- $\quad(1-y ; x-y ; z): 0.7432 ; 1.0848 ; 0.0704$

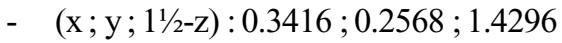

- $\quad(\mathrm{y}-\mathrm{x} ; 1-\mathrm{x} ; \mathrm{z}):-0.0848 ; 0.6584 ; 0.0704$

- $\quad\left(1-\mathrm{y} ; \mathrm{x}-\mathrm{y} ; 1 \mathrm{1} \frac{1}{2}-\mathrm{z}\right): 0.7432 ; 1.0848 ; 1.4296$

- $\quad$ and $(\mathrm{x} ; \mathrm{y} ; \mathrm{z}): 0.3416 ; 0.2568 ; 0.0704$

The second $\overline{6}$ axis at $(2 / 3 ; 1 / 3 ; z)$ gives the following points (Fig. 4):

- $\quad(1+y-x ; 1-x ; 1 / 2-z): 0.9152 ; 0.6584 ; 0.4296$

- $\quad(1-y ; x-y ; z): 0.7432 ; 0.0848 ; 0.0704$

- $\quad(\mathrm{x} ; \mathrm{y} ; 1 / 2-\mathrm{z}): 0.3416 ; 0.2568 ; 0.4296$

- $\quad(1+\mathrm{y}-\mathrm{x} ; 1-\mathrm{x} ; \mathrm{z}): 0.9152 ; 0.6584 ; 0.0704$

- $\quad(1-y ; x-y ; 1 / 2-z): 0.7432 ; 0.0848 ; 0.4296$

- $\quad$ and $(\mathrm{x} ; \mathrm{y} ; \mathrm{z}): 0.3416 ; 0.2568 ; 0.0704$

\section{Equivalent positions}

According to the translation due to the crystal lattice, all the previous points have their equivalents in the unit-cell. There are 12 points and their coordinates are (Fig. 2):

$$
(\mathrm{x} ; \mathrm{y} ; \mathrm{z}): 0.3416 ; 0.2568 ; 0.0704
$$




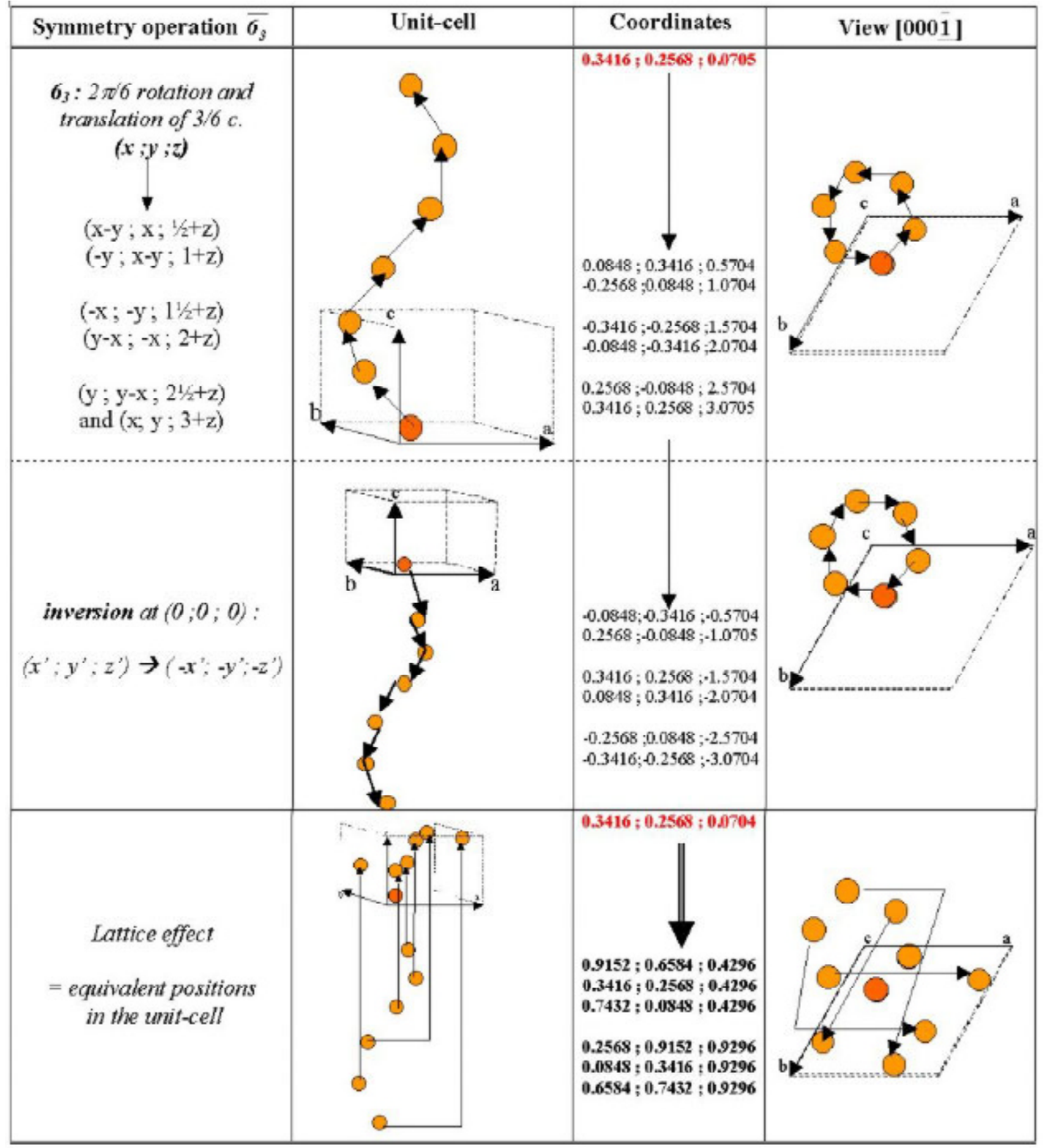

Figure 2: $\overline{\boldsymbol{6}_{3}}$ symmetry operations.

- $\quad(1-\mathrm{y} ; \mathrm{x}-\mathrm{y} ; \mathrm{z}): 0.7432 ; 0.0848 ; 0.0704$

- $\quad(\mathrm{y}-\mathrm{x} ; 1-\mathrm{x} ; \mathrm{z}): 0.9152 ; 0.6584 ; 0.0704$

- $\quad(1-\mathrm{x} ; 1-\mathrm{y} ; 1-\mathrm{z}): 0.6584 ; 0.7432 ; 0.9296$

- $\quad(\mathrm{y} ; \mathrm{y}-\mathrm{x} ; 1-\mathrm{z}): 0.2568 ; 0.9152 ; 0.9296$

- $\quad(\mathrm{x}-\mathrm{y} ; \mathrm{x} ; 1-\mathrm{z}): 0.0848 ; 0.3416 ; 0.9296$

- $\quad(1-\mathrm{x} ; 1-\mathrm{y} ; 1 / 2+\mathrm{z}): 0.6584 ; 0.7432 ; 0.5704$

- $\quad(y ; y-x ; 1 / 2+z): 0.2568 ; 0.9152 ; 0.5704$

- $\quad(\mathrm{x}-\mathrm{y} ; \mathrm{x} ; 1 / 2+\mathrm{z}): 0.0848 ; 0.3416 ; 0.5704$

- $\quad(\mathrm{x} ; \mathrm{y} ; 1 / 2-\mathrm{z}): 0.3416 ; 0.2568 ; 0.4296$

- $\quad(1-\mathrm{y} ; \mathrm{x}-\mathrm{y} ; 1 / 2-\mathrm{z}): 0.7432 ; 0.0848 ; 0.4296$

- $\quad(\mathrm{y}-\mathrm{x} ; 1-\mathrm{x} ; 1 / 2-\mathrm{z}): 0.9152 ; 0.6584 ; 0.4296$

The other atoms of the FAp molecule are subject to the same symmetry laws as the $\mathrm{O}_{\text {III }}$ atom. However, they are in special positions, i.e., at the position of one or more symmetry elements. Therefore they are not changed by these symmetry operations and the number of equivalent positions decreases.

$\mathrm{P}, \mathrm{O}_{\mathrm{I}}, \mathrm{O}_{\mathrm{II}}$ and $\mathrm{Ca}_{\mathrm{II}}$ atoms belong to the same point group $m\left(C_{s}\right)$, and are located in the same Wickoff position $h$. That means that the same transformations are applied to their coordinates, and hence the description of one atom is enough to find the other atoms. Therefore only the positions of $\mathrm{Ca}_{\mathrm{II}}{ }^{2+}$ ions, coordinates $(0.2416 ; 0.0071 ; 1 / 4)$, are described below. The positions of the other atoms are found with the general coordinates of the equivalent positions. 


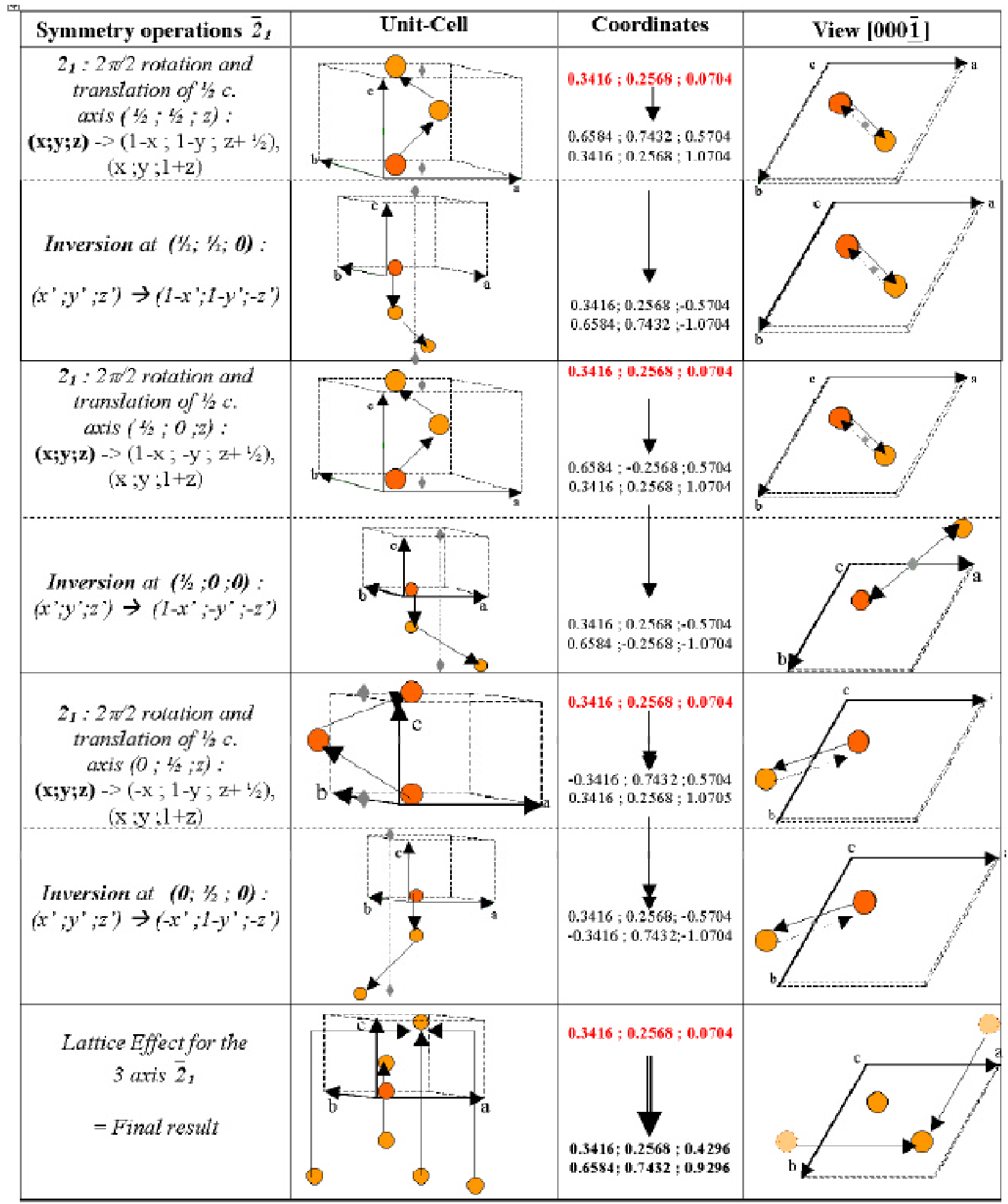

Figure 3: Description of the $\overline{2}_{1}$ symmetry operations.

\section{mirror plane $m$}

The $\mathrm{Ca}_{\mathrm{II}}{ }^{2+}$ ion, coordinates $(0.2416 ; 0.0071 ; 1 / 4)$, and the $\mathrm{P}, \mathrm{O}_{\mathrm{I}}$ and $\mathrm{O}_{\mathrm{II}}$ atoms are in the mirror plane, and therefore unaffected by this symmetry operation. However, the other symmetry operations $\overline{6}, \overline{2}$, and $\overline{6}$ axis influence these atoms. Only the positions of the $\mathrm{Ca}_{\mathrm{II}}^{2+}$ ion are described below.

\section{$\operatorname{axis} \overline{\mathbf{6}_{3}}$}

According to the $6_{3}$ axis, the $\mathrm{Ca}_{\mathrm{II}}{ }^{2+}$ ion is influenced by a series of operations composed of a $2 p / 6$ rotation and a translation of $3 / 6 c(=1 / 2 c)$. We obtained 6 new points :

- $\quad(\mathrm{x}-\mathrm{y} ; \mathrm{x} ; 1 / 2+\mathrm{z}): 0.2345 ; 0.2416 ; 3 / 4$

- $\quad(-\mathrm{y} ; \mathrm{x}-\mathrm{y} ; 1+\mathrm{z}):-0.0071 ; 0.2345 ; 1 \frac{1 / 4}{4}$

- $\quad\left(-\mathrm{x} ;-\mathrm{y} ; 1 \frac{1}{2}+\mathrm{z}\right):-0.2416 ;-0.0071 ; 13 / 4$

- $\quad(\mathrm{y}-\mathrm{x} ;-\mathrm{x} ; 2+\mathrm{z}):-0.2345 ;-0.2416 ; 21 / 4$,

- $\quad\left(\mathrm{y} ; \mathrm{y}-\mathrm{x} ; 2 \frac{1}{2}+\mathrm{z}\right): 0.0071 ;-0.2345 ; 2 \frac{3}{4}$ 


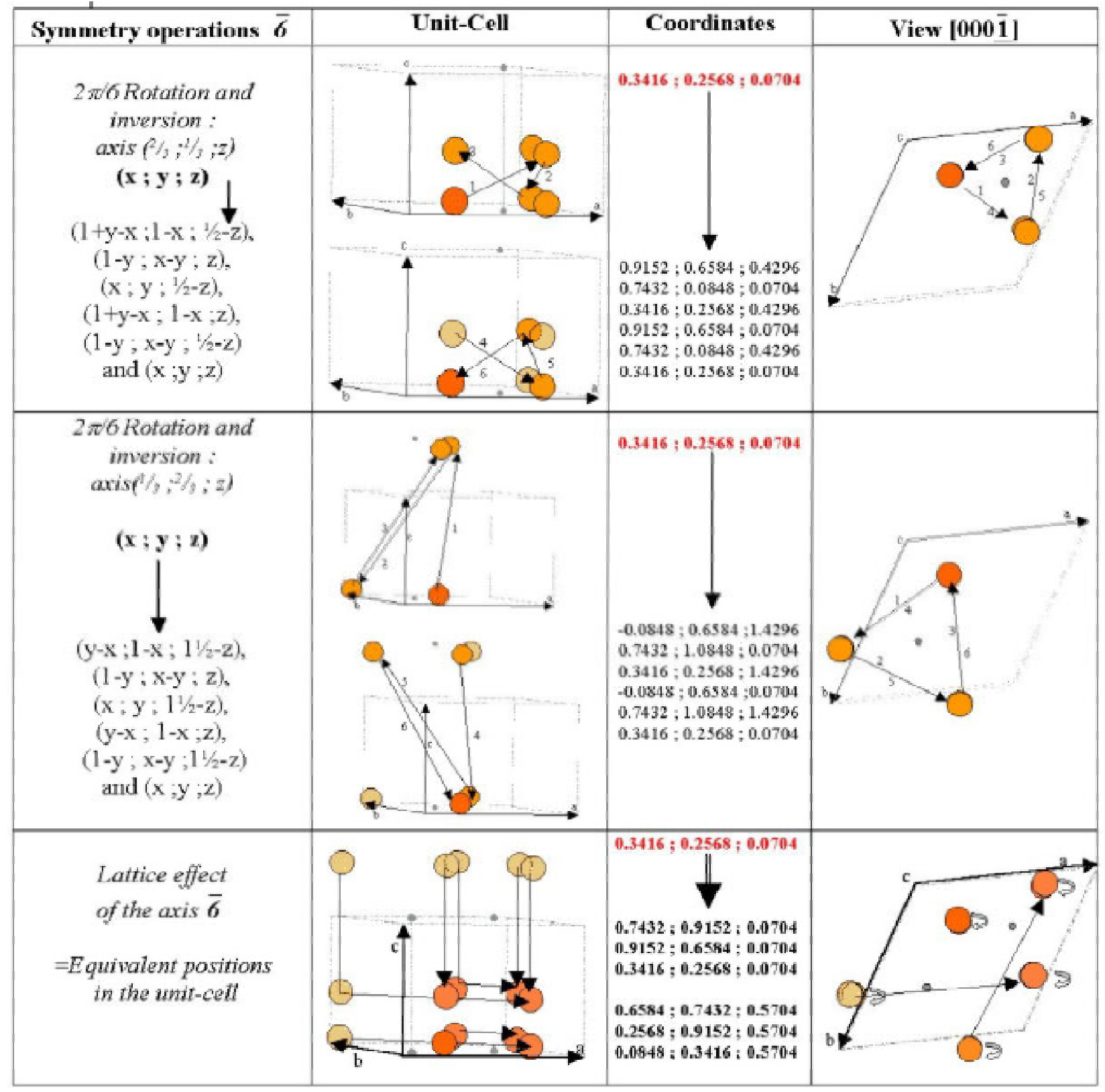

Figure 4: Description of the transformations induced by the $\overline{\mathbf{6}}$ axis

- $\quad$ and $(\mathrm{x} ; \mathrm{y} ; 3+\mathrm{z}): 0.2416 ; 0.0071 ; 3 \frac{114}{4}$

This last point is identical to the $(\mathrm{x} ; \mathrm{y} ; \mathrm{z})$ point, with a translation of $3 c$. The inversion point at the unit-cell origin transforms these atoms to $\left(-\mathrm{x}^{\prime} ;-\mathrm{y}^{\prime} ;-\mathrm{z}^{\prime}\right)$ :

- $(-0.2345 ;-0.2416 ;-3 / 4)$,

- $\quad\left(0.0071 ;-0.2345 ;-1 \frac{1 / 4}{4}\right)$,

- $\quad(0.2416 ; 0.0071 ;-13 / 4)$,

- $\quad\left(0.2345 ; 0.2416 ;-2^{1 / 4}\right)$,

- $\quad(-0.0071 ; 0.2345 ;-23 / 4)$

- $\quad$ and $\left(-0.2416 ;-0.0071 ;-3 \frac{1 / 4}{4}\right.$.

Most of these points are outside the unit-cell, but their equivalents are found in the unit-cell according to the lattice translations :

- $\quad(\mathrm{x} ; \mathrm{y} ; 1 / 4): 0.2416 ; 0.0071 ; 1 / 4$

- $\quad(1-(\mathrm{y}-\mathrm{x}) ; 1-\mathrm{x} ; 1 / 4): 0.7655 ; 0.7584 ; 1 / 4$

- $\quad(1-y ; x-y ; 1 / 4): 0.9929 ; 0.2345 ; 1 / 4$
- $\quad(1-\mathrm{x} ; 1-\mathrm{y} ; 3 / 4): 0.7584 ; 0.9929 ; 3 / 4$

- $\quad(\mathrm{x}-\mathrm{y} ; \mathrm{x} ; 3 / 4): 0.2345 ; 0.2416 ; 3 / 4$

- $\quad(\mathrm{y} ; 1-(\mathrm{y}-\mathrm{x}) ; 3 / 4): 0.0071 ; 0.7655 ; 3 / 4$

\section{axis $\overline{\mathbf{2}}_{1}$}

Under the influence of the 32 axis, the initial point occurs at $(1-\mathrm{x} ; 1-\mathrm{y} ; 1 / 2+\mathrm{z}),(1-\mathrm{x} ; \mathrm{y} ; 1 / 2+\mathrm{z})$, and $(\mathrm{x} ; 1-\mathrm{y} ; 1 / 2+\mathrm{z})$, i.e. for the $\mathrm{Ca}_{\mathrm{II}}{ }^{2+}$ ion : $(0.7584 ; 0.9929 ; 3 / 4),(0.7584 ; 0.0071 ; 3 / 4)$ and $(0.2416 ; 0.9929 ; 3 / 4)$ then at $\left(0.2416 ; 0.0071 .1 \frac{1 / 4}{4}\right)$. The inversion points at $(1 / 2 ; 1 / 2 ; 0),(1 / 2 ; 0 ; 0)$ and $(0 ; 1 / 2 ; 0)$ transform these atoms at $(0.2416 ; 0.0071 ;-3 / 4)$, then at $\left(0.7584 ;-0.0071 ;-1 \frac{11 / 4}{)},\left(0.7584 ; 0.9929 ;-1 \frac{11 / 4}{4}\right.\right.$, $\left(-0.2416 ; 0.9929 ;-1 \frac{1 / 4}{4}\right)$. By translations, these 3 positions give a unique equivalent in the unit-cell: the position $(1-\mathrm{x} ; 1-\mathrm{y} ; 3 / 4)$ i.e. $(0.7584 ; 0.9929 ; 3 / 4)$. 


\section{$\operatorname{axis} \overline{6}$}

For the operations due to the $\overline{6}$ axis at $(2 / 3 ; 1 / 3 ; \mathrm{z})$, the $\mathrm{Ca}_{\mathrm{II}}{ }^{2+}$ ion (and the $\mathrm{P}, \mathrm{O}_{\mathrm{I}}$ et $\mathrm{O}_{\mathrm{II}}$ atoms) reacts only to the inversion in its coordinates $\mathrm{x}$ and $\mathrm{y}$ because the inversion point is in the same plane as the $\mathrm{Ca}_{\mathrm{II}}{ }^{2+}$ ion, at $\left(2 /{ }_{3} ; 1 / 3,1 / 4\right)$. The successive rotations do not give 6 points located in 2 triangles at $\mathrm{z}=1 / 4$ and $\mathrm{z}=3 / 4$, but 3 points in a triangle at $\mathrm{z}=1 / 4$

- $\quad(1-y ; x-y ; 1 / 4): 0.9929 ; 0.2345 ; 1 / 4$

- $\quad(1+\mathrm{y}-\mathrm{x} ; 1-\mathrm{x} ; 1 / 4): 0.7655 ; 0.7584 ; 1 / 4$

- $\quad(\mathrm{x} ; \mathrm{y} ; 1 / 4): 0.2416 ; 0.0071 ; 1 / 4$.

The other $\overline{6}$ axis at $\left(1 /{ }_{3} ; 2 / 3 ; \mathrm{z}\right)$ has an inversion point at $(1 / 3 ; 2 / 3 ; 3 / 4)$ and gives 6 points:

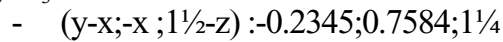

- $\quad(1-\mathrm{y} ; \mathrm{x}-\mathrm{y} ; \mathrm{z}): 0.9929 ;-0.2345 ; 1 / 4$

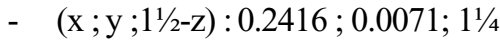

- $\quad(\mathrm{y}-\mathrm{x} ; 1-\mathrm{x} ; \mathrm{z}):-0.2345 ; 0.7584 ; 1 / 4$

- $\quad\left(1-y ; x-y ; 11 \frac{1}{2}-z\right): 0.9929 ;-0.2345 ; 11 / 4$

- $\quad$ and $(\mathrm{x} ; \mathrm{y} ; \mathrm{z}): 0.2416 ; 0.0071 ; 1 / 4$.

There are 3 equivalent points in the unit-cell : $(\mathrm{x} ; \mathrm{y} ; 1 / 4)$, $(1-(\mathrm{x}-\mathrm{y}) ; 1-\mathrm{x} ; 1 / 4)$ and $(1-\mathrm{y} ; 1-(\mathrm{x}-\mathrm{y}) ; 1 / 4)$, i.e. $(0.2416 ; 0.0071 ; 1 / 4),(0.7655 ; 0.7584 ; 1 / 4)$ and $(0.9929 ; 0.7655 ; 1 / 4)$.
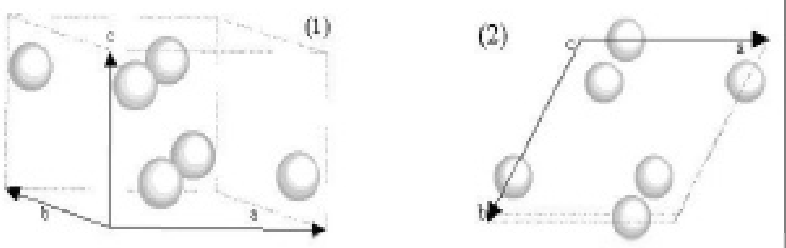

Figure 5: Equivalent positions of the $\mathrm{Ca}_{\mathrm{II}}^{2+}$ ions. (1) Unit-cell: (2) view [000 $\overline{1}]$
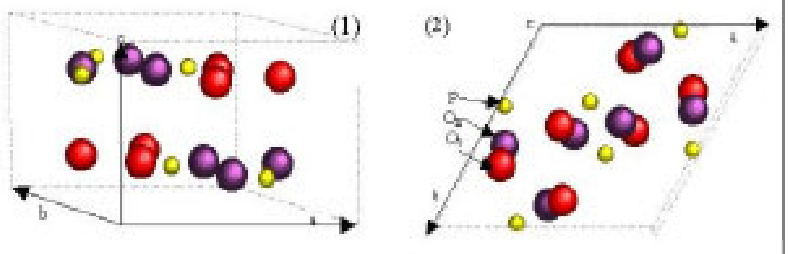

Figure 6: Equivalent positions of the $\mathrm{P}, \mathrm{O}_{\mathrm{I}}$ and $\mathrm{O}_{\mathrm{II}}$. atoms. (1) Unit-cell: (2) view [000 $\overline{1}]$

\section{Equivalent positions}

These symmetry operations give the same 6 equivalent positions, with identical coordinates (Figs. 5 and 6):

- $\quad(\mathrm{x} ; \mathrm{y} ; 1 / 4): 0.2416 ; 0.0071 ; 1 / 4$

- $\quad(1-\mathrm{y} ; \mathrm{x}-\mathrm{y} ; 1 / 4): 0.9929 ; 0.2345 ; 1 / 4$

- $\quad(\mathrm{y}-\mathrm{x} ; 1-\mathrm{x} ; 1 / 4): 0.7655 ; 0.7584 ; 1 / 4$

- $\quad(1-\mathrm{x} ; 1-\mathrm{y} ; 3 / 4): 0.7584 ; 0.9929 ; 3 / 4$

- $\quad(\mathrm{y} ; \mathrm{y}-\mathrm{x} ; 3 / 4): 0.0071 ; 0.7655 ; 3 / 4$

- $\quad$ and $(\mathrm{x}-\mathrm{y} ; \mathrm{x} ; 3 / 4): 0.2345 ; 0.2416 ; 3 / 4$.

The $\mathrm{Ca}_{\mathrm{I}}^{2+}$ ion, coordinates $\left(1 /{ }_{3} ;{ }^{2} / 3 ; 0.0011\right)$, is located in the symmetry site $3\left(C_{3}\right)$.

\section{mirror plane $\boldsymbol{m}$}

The mirror plane at $\mathrm{z}=1 / 4$ transforms the initial point to $(\mathrm{x} ; \mathrm{y} ; 1 / 2-\mathrm{z})$, i.e. $\left(1 / 3{ }_{3} ; 2 / 3 ; 0.4989\right)$.

\section{axis $\overline{6_{3}}$}

Under the influence of the $\sigma_{3}$ axis, the $\mathrm{Ca}_{\mathrm{I}}^{2+}$ ion is submitted to a series of operations, consisting of a $2 \mathrm{p} / 6$ rotation and a translation of $3 / 6 c(=1 / 2 c)$. We obtain 6 new points :

- $(\mathrm{x}-\mathrm{y} ; \mathrm{x} ; 1 / 2+\mathrm{z}):-1 / \frac{1}{3} ; 1 / \frac{1}{3} ; 0.5011$

- $\quad(-\mathrm{y} ; \mathrm{x}-\mathrm{y} ; 1+\mathrm{z}):-2 /{ }_{3} ;-1 / 3 ; 1.0011$

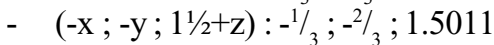

- $\quad(\mathrm{y}-\mathrm{x} ;-\mathrm{x} ; 2+\mathrm{z}): 1 / \frac{1}{3} ;-1 / 3 ; 2.0011$

- $\quad\left(\mathrm{y} ; \mathrm{y}-\mathrm{x} ; 2 \frac{1}{2}+\mathrm{z}\right): 2 /{ }_{3} ; 1 / 3 ; 2.5011$

- $\quad$ and $(\mathrm{x} ; \mathrm{y} ; 3+\mathrm{z}): 1 / 3{ }^{1 / 2}{ }_{3} ; 3.0011$.

The inversion point at the origin of the unit-cell transforms these atoms to 6 new points at (-x';-y';-z'):

- $(1 / 3 ;-1 / 3 ;-0.5011)$

- $(2 / 3 ; 1 / 3 ;-1.0011)$

- $(1 / 3,2 / 3 ;-1.5011)$

- $\quad(-1 / 3 ; 1 / 3 ;-2.0011)$

- $(-2 / 3 ;-1 / 3 ;-2.5011)$

- $\quad$ and $(-1 / 3 ;-2 / 3 ;-3.0011)$

Most of those points are outside the unit-cell, but their equivalents are found in the unit-cell with the lattice translations. Their coordinates are :

- $\quad(\mathrm{x} ; \mathrm{y} ; 1 / 2-\mathrm{z}): 1{ }_{3} ;{ }^{2} /{ }_{3} ; 0.4989$

- $\quad(1-\mathrm{x} ; 1-\mathrm{y} ; 1-\mathrm{z}): 2 /{ }_{3} ;{ }^{1 /} ; 0.9989$

\section{$\overline{2}$ axis}

Under the influence of the 2 axis, the initial point goes to (1-x ; 1-y ; 1/2-z), (1-x ; -y ; 1/2-z), and (-x ; 1-y ; 1/2-z), i.e. $(2 / 3 ; 1 / 3 ; 0.5011),(2 / 3 ;-2 / 3 ; 0.5011)$ and $(-1 / 3 ; 1 / 3 ; 0.5011)$, then at $(\mathrm{x} ; \mathrm{y} ; 1+\mathrm{z})$, i.e. $(1 / 3 ; 2 / 3 ; 1.0011)$. All the inversion points at $(1 / 2 ; 1 / 2 ; 0),(1 / 2 ; 0 ; 0)$ and $(0 ; 1 / 2 ; 0)$ give the same point at $(1 / 3 ; 2 / 3 ;-0.5011)$.

\section{$\overline{6}$ axis}

The $\mathrm{Ca}_{\mathrm{I}}^{2+}$ ion is located in the $\overline{6}$ axis, parallel to the $c$-axis at $(1 / 3 ; 2 / 3 ; \mathrm{z})$. Therefore it is not affected by the 6 rotation at $\left(1 /{ }_{3} ; 2 / 3 ; \mathrm{z}\right)$, but the inversion according to the $(1 / 3 ; 2 / 3.3)$ point gives $\left(1 /{ }_{3} ; 2 / 3 ; 1.4999\right)$, and then $\left(1 / 3{ }_{3} ;{ }_{3} /{ }_{3} ; 0.0011\right)$. The other axis, at $(2 / 3 ; 1 / 3 ; z)$, gives 6 points : $(1+y-x ; 1-x ; 1 / 2-z)$, (1-y ; x-y ; z), (x ;y ;1/2-z), (1+y-x ;1-x ;z), (1-y ; $-\mathrm{y} ; 1 / 2-\mathrm{z})$, and $(\mathrm{x} ; \mathrm{y} ; \mathrm{z})$, i.e. $\left({ }^{4} /{ }_{3} ;{ }^{2 / 3} ; 0.4989\right),\left(1 /{ }_{3} ;-1 /{ }_{3} ; 0.0011\right)$, $(2 / 3 ; 1 / 3 ; 0.4989),(4 / 3,2 / 3 ; 0.0011),(1 / 3 ;-1 / 3 ; 0.4989)$ and $(1 / 3 ; 2 / 3 ; 0.0011)$.

\section{Equivalent positions}

According to the particular coordinates $\mathrm{x}$ and $\mathrm{y}$ of the $\mathrm{Ca}_{\mathrm{I}}^{2+}$, $\mathrm{x}=1 / 3$ and $\mathrm{y}=2 / 3$. the different symmetry operations give identical positions. The $\mathrm{Ca}_{\mathrm{I}}^{2+}$ ion has 4 equivalent positions (Fig. 7) :

- $(\mathrm{x} ; \mathrm{y} ; \mathrm{z}): 1{ }_{3} ;{ }^{2 /}{ }_{3} ; 0.0011$

- $\quad(1-\mathrm{x} ; 1-\mathrm{y} ; 1-\mathrm{z}):{ }^{2 / 3} ;{ }_{3} /{ }_{3} ; 0.9989$

- $\quad(\mathrm{x} ; \mathrm{y} ; 1 / 2-\mathrm{z}): 1 /{ }_{3} ;{ }^{2 /}{ }_{3} ; 0.4989$

- $\quad(1-\mathrm{x} ; 1-\mathrm{y} ; 1 / 2+\mathrm{z}): 2 /{ }_{3} ; 1 / \frac{1}{3} ; 0.5011$ 


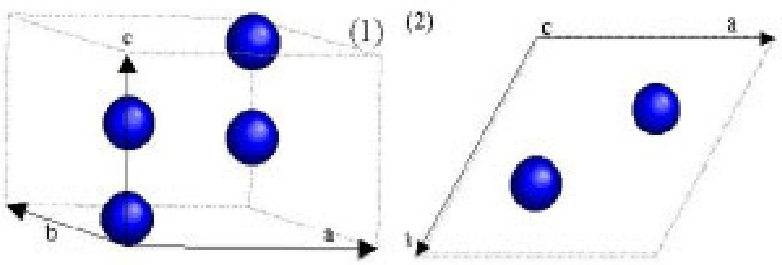

Figure 7: Equivalent positions of the $\mathrm{Ca}_{\mathrm{I}}^{2+}$ ion: (1) Unit-cell (2) View [000ㅜㅜ]

The $\mathrm{F}^{-}$ion, coordinates $(0 ; 0 ; 1 / 4)$, is located in the symmetry sites $\bar{\sigma}\left(C_{3 h}\right)$, and in the mirror plane, on the $6_{3}$ axis at the unit-cell origin. Moreover, its particular coordinates cause it to be unaffected by several symmetry operations.

\section{Mirror plane $m$}

The $\mathrm{F}^{-}$ion is located in the mirror plane at $\mathrm{z}=1 / 4$. Hence it is not influenced by the mirror symmetry.

\section{$\overline{6_{3}}$ axis}

The presence of the $\mathrm{F}^{-}$ion on the $c$-axis causes it to be unaffected by the 6 rotation. But the translation of $3 / 6 c$ due to the $6_{3}$ axis gives the point $(0 ; 0 ; 3 / 4)$, then the same at $z=1 \frac{1 / 4}{4}, 1 \frac{3}{4}, 2 \frac{1}{4}, 23 / 4$ and $3 \frac{1}{4}$. The inversion due to the point $(0 ; 0 ; 0)$ gives $(0 ; 0 ;-3 / 4)$, then $z=-1 \frac{1}{4},-1 \frac{3}{4},-2 \frac{1}{4},-2 \frac{3}{4}$ and $-31 / 4$, which gives by translations in the unit-cell $(0 ; 0 ; 1 / 4)$, which is the initial point and $(0 ; 0 ; 3 / 4)$.

\section{$\overline{2_{1}}$ axis}

With the 2 axis, the $\mathrm{F}^{-}$ion is submitted to a $2 \mathrm{p} / 2$ rotation and a translation of $1 / 2 c$. Its new positions are :

$$
\begin{array}{ll}
- & (1-\mathrm{x} ; 1-\mathrm{y} ; 1 / 2+\mathrm{z}): 1 ; 1 ; 3 / 4 \\
- & (1-\mathrm{x} ;-\mathrm{y} ; 1 / 2+\mathrm{z}): 1 ; 0 ; 3 / 4 \\
- & (-\mathrm{x} ; 1-\mathrm{y} ; 1 / 2+\mathrm{z}): 0 ; 1 ; 3 / 4
\end{array}
$$

The succession of this operation goes outside the unit-cell at $(\mathrm{x} ; \mathrm{y} ; 1+\mathrm{z})$, i.e. $\left(0 ; 0 ; 1 \frac{1 / 4}{4}\right)$. The inversion points $(1 / 2 ;$ $1 / 2 ; 0),(1 / 2 ; 0 ; 0)$ at $(0 ; 1 / 2 ; 0)$ transform the coordinates $\left(\mathrm{x}^{\prime} ; \mathrm{y}^{\prime} ; \mathrm{z}^{\prime}\right)$ to $(1-\mathrm{x} ; 1-\mathrm{y} ;-\mathrm{z}),(1-\mathrm{x} ;-\mathrm{y} ;-\mathrm{z})$, to $(-\mathrm{x} ; 1-\mathrm{y} ;-\mathrm{z})$. Because of the particular coordinates of the $\mathrm{F}^{-}$ions, this symmetry operation is similar to a transformation of the 3 points to the point $(0 ; 0 ; 1 / 4)$, the initial point, then to $(1 ; 1 ;-1 / 4),(1 ; 0 ;-1 / 4)$ and $(0 ; 1 ;-1 / 4)$. These 3 last points are equivalent to $(0 ; 0 ; 3 / 4)$.

\section{$\overline{6}$ axis}

The first $\overline{6}$ axis located at $\left(1 /{ }_{3} ; 2 / 3 ; \mathrm{z}\right)$ gives the following points :

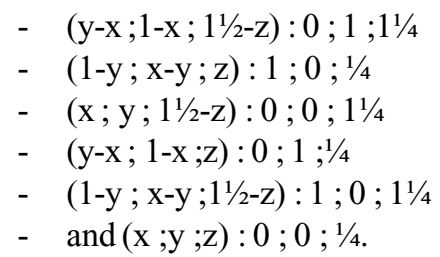

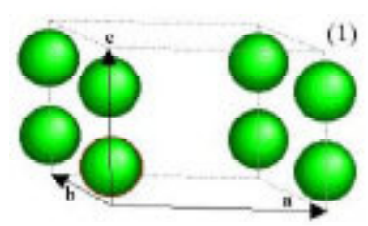

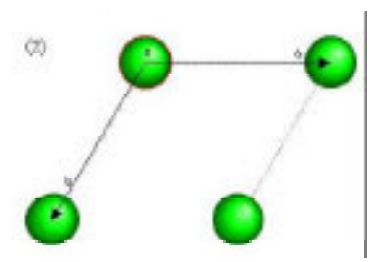

Figure 8: Equivalent positions of the $\mathrm{F}^{-}$ion: (1) Unitcell. (2) View [000̄̄]

The second $\overline{6}$ axis located at $\left(2 /{ }_{3} ;{ }_{1 / 3} ; \mathrm{z}\right)$ has an inversion point located in the same plane as the $\mathrm{F}^{-}$ion. Therefore only 3 points are obtained:

- $(1-\mathrm{y} ; \mathrm{x}-\mathrm{y} ; \mathrm{z}): 1 ; 0 ; 1 / 4$

- $\quad(1+\mathrm{y}-\mathrm{x} ; 1-\mathrm{x} ; \mathrm{z}): 1 ; 1 ; 1 / 4$

- $\quad$ and $(\mathrm{x} ; \mathrm{y} ; \mathrm{z}): 0 ; 0 ; 1 / 4$

\section{Equivalent positions}

The 2 equivalent positions of the $\mathrm{F}^{-}$ions are $(0 ; 0 ; 1 / 4)$ and $(0 ; 0 ; 3 / 4)$. These atoms are on an axis of the unit-cell because of the null coordinates $\mathrm{x}$ and $\mathrm{y}$, so they are generated on the 3 other faces by translations. These new positions are : $(1 ; 0 ; 1 / 4),(1 ; 0 ; 3 / 4),(0 ; 1 ; 1 / 4),(0 ; 1 ; 3 / 4)$, $(1 ; 1 ; 1 / 4)$ and $(1 ; 1 ; 3 / 4)$. (Fig. 8$)$

With the lattice translations, the crystal symmetries are not evident when only one unit-cell is observed. Only the observation of several adjacent unit-cells allows the visualisation of all the lattice symmetries (Fig. 9).

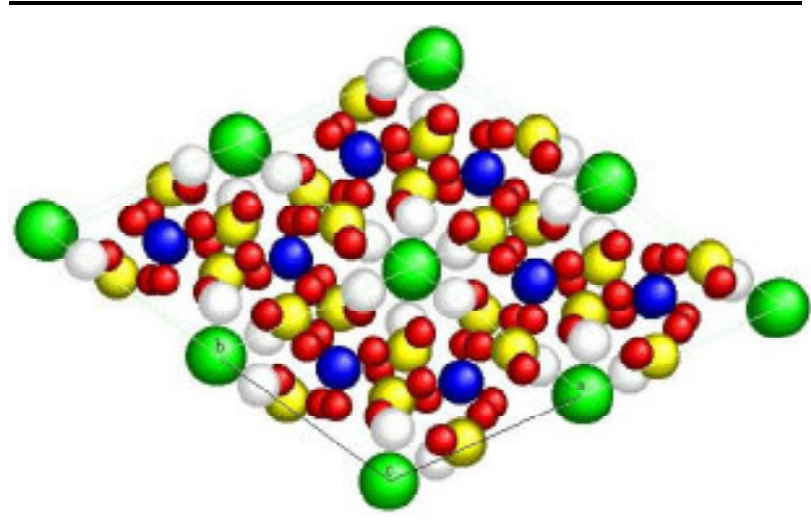

Figure 9: FAp crystal (2x2 cells - View [0001])

$\mathrm{PO}_{4}^{3-}$ ions are the only polyatomic ions of the FAp crystal. A phosphorus atom (valence: +5 ) is bonded to 4 oxygen atoms (valence: -2 ). If the $\mathrm{PO}_{4}{ }^{3-}$ ion is totally isolated from crystal interactions, it can be drawn as a perfect tetrahedron, where the $\mathrm{P}$ atom is the gravity centre, and the $\mathrm{O}$ atoms the edges of the tetrahedron. In the ideal model, the P-O covalent bonds are $1.54 \AA$ long (Radhakrishnan 1963, 1964) and the distance between two $\mathrm{O}$ atoms is $2.51 \AA$ long. The $\mathrm{O}_{\mathrm{i}}-\mathrm{P}-\mathrm{O}_{\mathrm{j}}(\mathrm{i} \neq \mathrm{j})$ angles are equal to $109^{\circ} 30^{\prime} 16^{\prime \prime}$. This molecule belongs to the cubic point group $\operatorname{Td}(\overline{4} 3 \mathrm{~m})$. The $\mathrm{P}-\mathrm{O}$ bonds are all equal, and there is no $\mathrm{P}=\mathrm{O}$ bond, which is logical considering the valences of the $\mathrm{P}$ and $\mathrm{O}$ atoms. So a non-defined bond exists and is located on the $4 \mathrm{O}$ Atoms and around the $\mathrm{P}$ atom. 
To find the $\mathrm{PO}_{4}^{3-}$ ions in the FAp crystal, the atomic positions of $\mathrm{P}$ and $\mathrm{O}$ atoms have to be considered (Table 1). $\mathrm{P}, \mathrm{O}_{\mathrm{I}}$ and $\mathrm{O}_{\mathrm{II}}$ atoms occur in the mirror-plane and form the basis of the $\mathrm{PO}_{4}^{3-}$ ion. The tetrahedron is completed by two $\mathrm{O}_{\text {III }}$ atoms out of the mirror planes and symmetrical by reflection. The covalent bonds still exists, but the tetrahedron is deformed according to the interactions between the $\mathrm{PO}_{4}^{3-}$ ion and its environment. The $\mathrm{PO}_{4}^{3-}$ ion is bonded to the local $\mathrm{Ca}^{2+}$ ions by way of its $\mathrm{O}$ atoms. These interactions distort the tetrahedron along the $c$-axis, the equality between the $\mathrm{P}-\mathrm{O}$ bonds and between the $\mathrm{O}_{\mathrm{i}}-\mathrm{P}-\mathrm{O}_{\mathrm{j}}(\mathrm{i} \neq \mathrm{j})$ angles is broken, except for the two atoms $\mathrm{O}_{\text {IIIa }}$ and $\mathrm{O}_{\text {IIIb }}$, which remain equivalent. This means a decrease of the molecular symmetry, and the $T d(\overline{4} 3 \mathrm{~m})$ point group becomes the $C s(m)$ site group. The bonds and angles of the $\mathrm{PO}_{4}^{3-}$ ion are (Sudarsanan et al., 1978) :

- $\quad \mathrm{P}-\mathrm{O}_{\mathrm{I}}=1.5337 \AA, \mathrm{P}_{-} \mathrm{O}_{\mathrm{II}}=1.5406 \AA, \mathrm{P}-\mathrm{O}_{\mathrm{III}}=1.5342 \AA$,

- $\mathrm{O}_{\mathrm{I}} \cdots \mathrm{O}_{\mathrm{II}}=2.538 \AA, \mathrm{O}_{\mathrm{I}} \cdots \mathrm{O}_{\mathrm{III}}=2.529 \AA, \mathrm{O}_{\mathrm{II}} \cdots \mathrm{O}_{\mathrm{III}}=2.487$ $\AA, \mathrm{O}_{\text {IIIIa }} \mathrm{O}_{\text {IIIb }}=2.473 \AA$,

- $\mathrm{O}_{\mathrm{I}}-\mathrm{P}-\mathrm{O}_{\mathrm{II}}=111^{\circ} 12^{\prime}, \mathrm{O}_{\mathrm{I}}-\mathrm{P}-\mathrm{O}_{\mathrm{III}}=111^{\circ} 06^{\prime} 36^{\prime \prime}, \mathrm{O}_{\mathrm{II}}-\mathrm{P}-\mathrm{O}_{\mathrm{III}}$ $=107^{\circ} 57^{\prime} 36^{\prime \prime}$ and $\mathrm{O}_{\mathrm{IIIa}}-\mathrm{P}-\mathrm{O}_{\mathrm{IIIb}}=107^{\circ} 19^{\prime} 48^{\prime \prime}$.

However, the decrease of the symmetry and the P-O variations are not enough to destroy the non-defined bond, which favours the interaction between the $\mathrm{PO}_{4}{ }^{3-}$ ion and its environment. Each $\mathrm{PO}_{4}^{3-}$ ion is bonded to $\mathrm{a} \mathrm{Ca}_{\mathrm{I}}{ }^{2+}$ ion by its two $\mathrm{O}_{\text {III }}$ atoms and by $\mathrm{O}_{\mathrm{I}}$ or $\mathrm{O}_{\mathrm{II}}$, and to an adjacent $\mathrm{Ca}_{\mathrm{I}}^{2+}$ ion by the 4th $\mathrm{O}$ atom $\left(\mathrm{O}_{\mathrm{II}}\right.$ or $\left.\mathrm{O}_{\mathrm{I}}\right)$. In the same way, the $\mathrm{PO}_{4}^{3-}$ ion interacts with a $\mathrm{Ca}_{\mathrm{II}}^{2+}$ ion by the $2 \mathrm{O}_{\mathrm{III}}$ atoms, and 2 adjacent $\mathrm{Ca}_{\mathrm{II}}{ }^{2+}$ ions by $\mathrm{O}_{\mathrm{I}}$ or $\mathrm{O}_{\mathrm{II}}$ (Fig. 10).

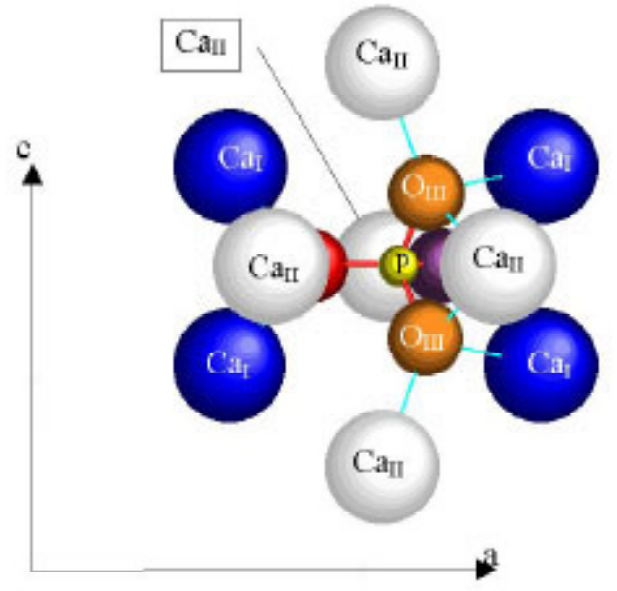

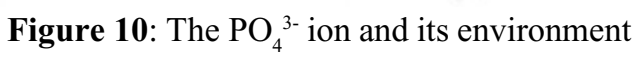

The $\mathrm{Ca}_{\mathrm{I}}{ }^{2+}$ ions are spaced by $c / 2$ and form columns along the $\overline{6}$-axis at $\left(1 / 3{ }_{3} ;{ }^{2} / 3 ; \mathrm{z}\right)$ and $\left(2 / 3,1{ }_{3} ; \mathrm{z}\right)$. Each $\mathrm{Ca}_{\mathrm{I}}{ }^{2+}$ ion is bonded to the $\mathrm{Ca}_{\mathrm{I}}^{2+}$ ions above and below it by $3 \mathrm{O}$ atoms from the mirror plane: $3 \mathrm{O}_{\mathrm{I}}$ above it, and $3 \mathrm{O}_{\mathrm{II}}$ below it. The distance between $\mathrm{Ca}_{\mathrm{I}}^{2+}$ and $\mathrm{O}_{\mathrm{I}}$ is $2.399 \AA$ long and between $\mathrm{Ca}_{\mathrm{I}}^{2+}$ and $\mathrm{O}_{\mathrm{II}} 2.457 \AA$ long. The $\mathrm{Ca}_{\mathrm{I}}^{2+}$ ion also interacts with $3 \mathrm{O}_{\mathrm{III}}$ atoms, which are about in the same plan as the $\mathrm{Ca}_{\mathrm{I}}{ }^{2+}$ ion (distance between $\mathrm{Ca}_{\mathrm{I}}^{2+}$ and $\mathrm{O}_{\mathrm{III}}: 2.807$ $\AA$ ). So the $\mathrm{Ca}_{1}^{2+}$ ions are bonded to $9 \mathrm{O}$ atoms by ionic bonds, and in this way they interact with the $\mathrm{PO}_{4}^{3-}$ ions (see Fig. 11).

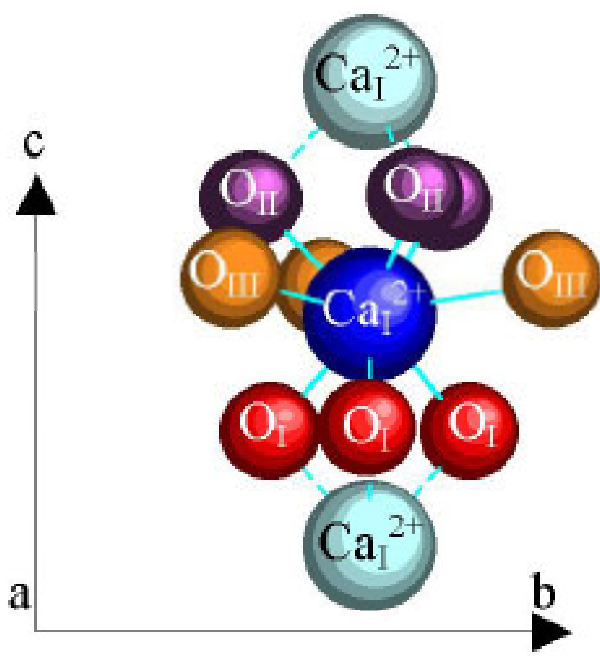

Figure 11: The $\mathrm{Ca}_{\mathrm{I}}^{2+}$ ion and its environment

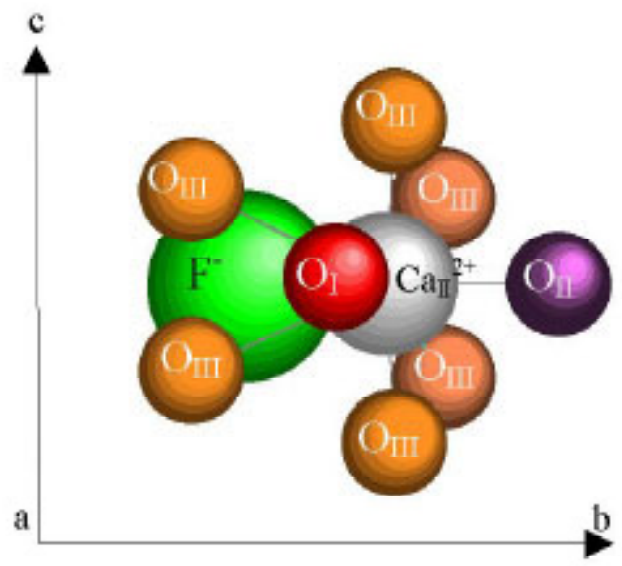

Figure 12: $\mathrm{The}_{\mathrm{Ca}}{ }_{\mathrm{II}}^{2+}$ ion and its environment

The $\mathrm{Ca}_{\mathrm{II}}^{2+}$ ions are in the mirror-planes, and form triangles around the $6_{3}$-axis. The $\mathrm{Ca}_{\mathrm{II}}^{2+}$ ion is coordinated to a $\mathrm{F}^{-}$ion, which is in the centre of the triangle $\left(\mathrm{d}\left(\mathrm{Ca}_{\mathrm{II}}^{2+} ; \mathrm{F}\right)=2.310 \AA\right.$ ) , and to $6 \mathrm{O}$ atoms (one $\mathrm{O}_{\mathrm{I}}$, one $\mathrm{O}_{\mathrm{II}}$ and $4 \mathrm{O}_{\text {III }}$ ) (Fig. 12). The distance between $2 \mathrm{Ca}_{\mathrm{II}}{ }^{2+}$ ions is between 4.002 and $4.084 \AA$ (Hughes et al., 1989) according to the position of the $2 \mathrm{Ca}_{\mathrm{II}}^{2+}$ ions (in the same mirror-plane or not). The distance between $\mathrm{Ca}_{\mathrm{II}}{ }^{2+}$ ion and $\mathrm{O}$ atoms is equal to 2.701. 2.374 and 2.501 $\AA$ respectively for $\mathrm{O}_{\mathrm{I}}, \mathrm{O}_{\mathrm{II}}$ and $\mathrm{O}_{\mathrm{III}}$. All the bonds are ionic except the $\mathrm{Ca}_{\mathrm{II}}-\mathrm{F}$ bond, which is partially covalent (Penel et al., 1997).

Each $\mathrm{F}^{-}$ion is bonded to the $\mathrm{F}^{-}$ions above and below it $(\mathrm{d}(\mathrm{F} ; \mathrm{F})=3.44 \AA)$ and to $3 \mathrm{Ca}_{\mathrm{II}}{ }^{2+}$ ions $\left(\mathrm{d}\left(\mathrm{F} ; \mathrm{Ca}_{\mathrm{II}}\right)=2.463 \AA\right)$ which form a triangle around it in the same mirror-plane

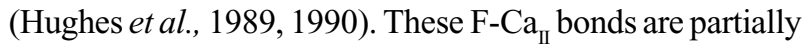
covalent (Penel et al., 1997) (Fig. 13).

The crystalline structure (Fig. 14) is a succession of columns parallel to the $c$-axis, at the centre of the triangles perpendicular to the $c$-axis: the $\mathrm{F}^{-}$ions are in the centre of $\mathrm{Ca}_{\mathrm{II}}{ }^{2+}$ triangles and the $\mathrm{Ca}_{\mathrm{I}}^{2+}$ ions are in the centre of $\mathrm{PO}_{4}^{3-}$ triangles. This structure and the presence of numerous ionic bonds make FAp a very suitable host for many of substituents or dopants. 


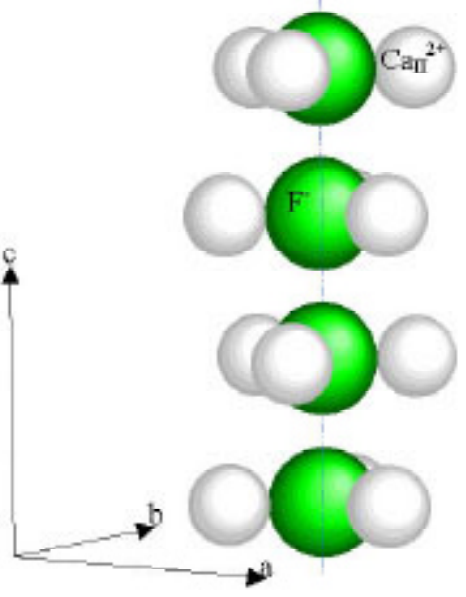

Figure 13 : Column of $\mathrm{F}^{-}$ions

\section{Substitutions}

Many types of substitution have been described, according the preferred substitution site. The main one, called TypeA substitution, is the substitution of the $\mathrm{F}^{-}$ion by another ion $\mathrm{X}^{-}\left(\mathrm{X}=\mathrm{Cl}, \mathrm{OH}, \mathrm{CO}_{3} \ldots\right)$ (Elliott, 1994; 1998; Hughes et al., 1989; 1990; 1991; Kay et al., 1964; Mackie and Young, 1974; O’Shea et al., 1974; Penel et al., 1997; Sudarsanan and Young, 1978). The second one is the $\mathrm{PO}_{4}^{3-}$ substitution (Penel et al., 1997; Perdikatsis, 1991), called Type-B substitution. Some ions can substitute for the $\mathrm{Ca}^{2+}$ ions: $\mathrm{Pb}^{2+}, \mathrm{Nd}^{2+}, \mathrm{Na}^{+}$(Elliot, 1994; Mackie and Young, 1973; Miyake et al., 1986). Finally, some dopants do not substitute at any particular site, but occur in a special position, which modifies the crystalline environment, e.g., $\mathrm{Sb}^{2+}$ or $\mathrm{Mn}^{2+}$ (DeBoer et al., 1991; Hughes et al., 1991; Suitch et al., 1985). All the substitutions exist in nature, and most of them are reproducible in the laboratory.

\section{The Type-A Substitution}

This consists of replacing $\mathrm{F}^{-}$ions by other $\mathrm{X}^{-}$ions $(\mathrm{X}=\mathrm{OH}$, $\mathrm{Cl}, \mathrm{Br})$ or $\mathrm{Y}^{2-}\left(\mathrm{Y}=\mathrm{O}, \mathrm{CO}_{3}\right)$. Replacement of $\mathrm{F}^{-}$by a neutral molecule is also possible $\left(\mathrm{H}_{2} \mathrm{O}, \mathrm{O}_{2}, \mathrm{Ar}, \mathrm{CO}_{2}\right)$ (Elliot 1994; Trombe, 1973). This implies a weak increase of the $a$-parameter. However, a neutral molecule substitution, e.g., by $\mathrm{H}_{2} \mathrm{O}$ or $\mathrm{O}_{2}$, only exists in a few particular conditions, e.g., the hydration of enamel.

The most usual substitution is substitution of the $\mathbf{F}^{-}$ ion by another monovalent ion, e.g., $\mathrm{OH}^{-}$or $\mathrm{Cl}^{-}$ions. The $\mathrm{X}^{-}$substituent is not exactly in the centre of the $\mathrm{Ca}_{\mathrm{II}}$ atoms triangle, at $z=1 / 4$ or $z=3 / 4$, but undergoes a displacement off these positions in the anionic column. This displacement varies according to the type of substituent: in hydroxyapatite (OHAp), the oxygen atom of the hydroxyl group is below or above the $\mathrm{Ca}_{\mathrm{II}}^{2+}$ triangles at $0.3 \AA$ of the $\mathrm{F}^{-}$position $(0 ; 0 ; 0.196)$, which causes a local disturbance (Hughes et al., 1989; Kay et al., 1964; Sudarsanan and Young, 1978). When the composition is close to a stoichiometric OHAp, the hydroxyl ions are always in these positions, and the space group becomes $P 2_{l} / b$ (Elliot 1994; Hughes et al., 1989) , with a pseudo-hexagonal structure $\left(b=2 a, g=120^{\circ}\right)$ (Fig. 15).

In the same way, in a stoichiometric chlorapatite (ClAp),

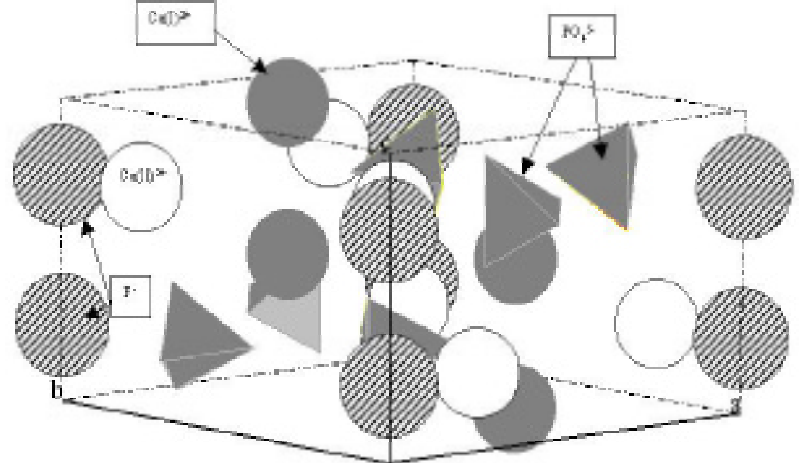

Figure 14: FAp unit cell viewed along the [0001] direction

the $\mathrm{Cl}^{-}$ions are in $(0 ; 0 ; 0.444)$. A vacancy is created on the $c$-axis and the space group becomes $P 2 / b$ (Sudarsanan and Young, 1978). In the series between the two (ClAp and FAp) stoichiometric apatites, the displacement of $\mathrm{X}^{-}$ ions implies that of $\mathrm{F}^{-}$ions according to their substitution rate, and causes a local disturbance, with a possible transformation from the hexagonal structure (space group $P 6_{3} / m$ ) to a monoclinic one (space group $P 2 / b$ ) (Hughes et al., 1989; 1990; Mackie and Young, 1974; Penel et al., 1997; Sudarsanan and Young, 1978). The presence of F-X interactions first stabilises the hexagonal structure, then causes the transformation to a monoclinic structure (Hughes et al., 1989; 1990). On the other hand, the unit-cell parameters are weakly modified: we note an increase of the $a$-parameter, and a decrease of the $c$-parameter (Hughes et al., 1989; 1990). The anionic site environment undergoes some disturbance depending on the substitution rate. No $\mathrm{PO}_{4}^{3-}$ or $\mathrm{Ca}^{2+}$ ions are lost, but a change of their crystallographic positions is observed, in order to conserve the $\mathrm{Ca}-\mathrm{X}$ bonds and to compensate the disorder due to the substitution. Then, we can observe a variation of about 0.2 percent of some crystallographic positions of $\mathrm{PO}_{4}{ }^{3-}$ and $\mathrm{Ca}^{2+}$ ions when the quantity of $\mathrm{F}^{-}$ions in the unit-cell decreases from 94 to 75\% (Mackie and Young, 1973; Sudarsanan and Young, 1978).

In a $\mathrm{Y}^{2-}$ ion substitution $\left(\mathrm{Y}=\mathrm{O}, \mathrm{CO}_{3}\right)$, the two $\mathrm{F}^{-}$ions of the unit-cell are substituted by one or more $\mathrm{Y}^{2-}$ ions (Elliott, 1998). This substitution can cause electrical charge

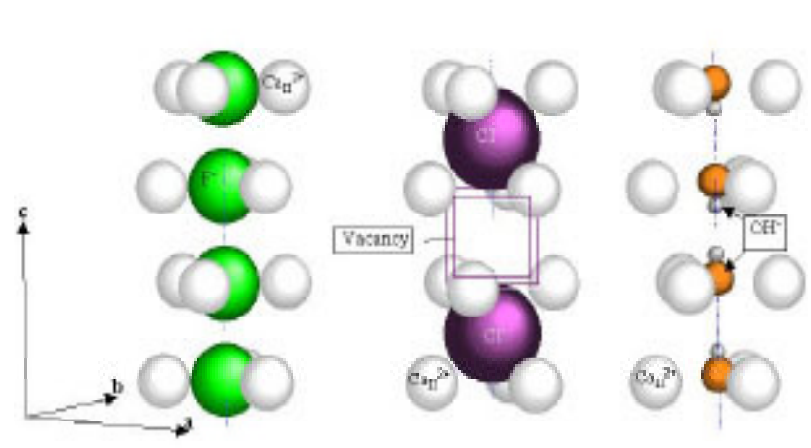

Figure 15: Apatite, $\mathrm{F}^{-}, \mathrm{OH}^{-}$and $\mathrm{Cl}^{-}$columns 
balance disorders, compensated by the existence of vacancies at $\mathrm{F}^{-}$ion sites or in some cases by a loss of the screw-axis $6_{3}$. Those $\mathrm{F}^{-}$vacancies could appear in order to compensate for a loss of one or several $\mathrm{Ca}^{2+}$ ions too.

The $\mathrm{Ca}^{2+}$ substitution is often present in industrial applications, where rare-earth-doped FAp (e.g., $\mathrm{Mn}^{2+}, \mathrm{Nd}^{3+}$, or $\mathrm{Sr}^{2+}$ ) (Fleet and Pan, 1997; Hughes et al., 1991; Mackie and Young, 1973; Suitch et al., 1985) are used to build fluorescence lamps. We find 2 or 3 types of $\mathrm{Ca}^{2+}$ substitutions, depending on whether the substituted sites are the $\mathrm{Ca}_{\mathrm{I}}^{2+}$ sites, the $\mathrm{Ca}_{\mathrm{II}}{ }^{2+}$ sites or both sites. Generally, if the substituent does not have a valence equal to +2 , the 2 sites are disturbed (Elliott 1994). If the substituent is in $\mathrm{M}^{2+}$ form, the substitution depends on the relative size of the substituent and the $\mathrm{Ca}^{2+}$ ion. According to Kreidler, the substituent radius for the $\mathrm{Ca}^{2+}$ site can be between 0.95 and $1.35 \AA$ (Kreidler and Hummel, 1970). The largest substituents prefer the $\mathrm{Ca}$ (II) site, and the FAp hexagonal structure suffers when small cations $\mathrm{M}^{2+}$ fill $\mathrm{Ca}_{\mathrm{I}}^{2+}$ sites (Elliot, 1994; Kreidler and Hummel, 1970).

The $\mathrm{Ca}^{2+}$ substitution by monovalent ions $\left(\mathrm{K}^{+}, \mathrm{Na}^{+}\right)$ takes often place on $\mathrm{Ca}_{\mathrm{I}}$ sites (Elliott 1994), creating a vacancy in $\mathrm{F}^{-}$sites, and sometimes in $\mathrm{Ca}_{\mathrm{I}}^{2+}$ sites.

If the substituent is divalent $\left(\mathrm{Sr}^{2+}, \mathrm{Pb}^{2+}, \mathrm{Mg}^{2+}\right)$, the preferentially substituted site is the $\mathrm{Ca}_{\mathrm{II}}{ }^{2+}$ site (Hughes et al., 1991; Miyake et al., 1986). We observed no loss of $\mathrm{PO}_{4}^{3-}$ ions, and the substitution rate is generally weak. The presence of dopant causes a contraction of the $c$-axis, an increase of the $a$-axis parameter (Hughes et al., 1991), and a weak displacement of the different atoms. The substitution rate is $1: 1$, and the crystalline structure does not seem to be particularly troubled by the possible electronic disorder. We only noted an extension of the $\mathrm{Ca}_{\mathrm{II}} \mathrm{O}$ distances, when they still existed (Hughes et al. 1991).

In the same way, when the two sites are substituted, the crystal sustained no major structural change (for example, substitution by $\mathrm{Pb}^{2+}$ (Miyake et al., 1986) or by $\mathrm{Cd}^{2+}$ (Nounah and Lacout, 1992)). We just noted a increase of the unit-cell parameters and of $\mathrm{M}-\mathrm{O}$ distances $(\mathrm{M}=\mathrm{Ca}$, $\mathrm{Cd}$ or $\mathrm{Pb}$ ). On the other hand, $\mathrm{a} \mathrm{Ca}_{\mathrm{I}}^{2+}$ substitution had many consequences for the crystalline structure (Hughes et al., 1991; Suitch et al., 1985). A weak $\mathrm{Mn}^{2+}$ rate (occupation rate inferior to 0.42 ) does not cause large crystalline changes, because the $\mathrm{Mn}^{2+}$ ion is smaller than the $\mathrm{Ca}^{2+}$ ion and fits better into the $\mathrm{Ca}(\mathrm{I})^{2+}$ surroundings rather than the $\mathrm{Ca}_{\mathrm{II}}^{2+}$ surroundings. We only observed a reduction of $\mathrm{Ca}_{\mathrm{I}}-\mathrm{O}$ distances (Hughes et al., 1991; Suitch et al., 1985). However, a substitution rate higher than or equal to $48 \%$ had more extensive consequences. $\mathrm{A} \mathrm{Ca}_{\mathrm{I}}^{2+}$ substitution by a $\mathrm{Mn}^{2+}$ ion excluded any other $\mathrm{Mn}^{2+}$ ion from the cell in the $\mathrm{Ca}_{\mathrm{I}}^{2+}$ site, excluded them in the $\mathrm{Ca}_{\mathrm{II}}^{2+}$ site and caused the appearance of a vacancy in $\mathrm{F}^{-}$sites (Elliott, 1994). Part of the $\mathrm{O}_{\mathrm{III}}$ atoms were rejected from their positions, and the plane-mirrors disappeared. The crystal symmetry was broken, and the space group became $P 6_{3}$ (Suitch et al., 1985).

$\mathrm{A} \mathrm{Ca}^{2+}$ substitution by a trivalent substituant $\left(\mathrm{Sb}^{3+}, \mathrm{Nd}^{3+}\right)$ is relatively seldom seen. However, this type of substitution is used in the fabrication of fluorescent lamps. If the substituent rate is very weak $(<2 \%)$, the $\mathrm{Ca}_{\mathrm{II}}{ }^{2+}$ sites are preferentially substituted, and we note no loss of $\mathrm{PO}_{4}^{3-}$. The crystal seems to accept the electronic disorder (DeBoer et al., 1991). The presence of dopant causes a reduction of the $c$-axis parameter, and an extension of the $a$-axis (Mackie and Young, 1973). The substitution ratio is $1: 1$, and the crystalline structure seems not affected by the eventual electronic disorder. However, when the substitution rate is higher, $\mathrm{Ca}^{2+}$ substitution by trivalent ions is accompanied by $\mathrm{F}^{-}$substitutions by divalent ions and/or $\mathrm{Ca}^{2+}$ substitutions by monovalent ions (Elliot, 1994). In the particular case of $\mathrm{Sb}^{3+}$ substitution, the $\mathrm{Sb}^{3+}$ size is more important than the $\mathrm{Ca}^{2+}$ size. When the substitution rate is over $3 \%$, the $\mathrm{Sb}^{3+}$ ions do not find a place in the $\mathrm{Ca}_{\mathrm{II}}{ }^{2+}$ sites but in $(1 / 3 ; 2 / 3 ; 1 / 4)$ and $(2 / 3,1 / 3 ; 1 / 4)$, between the $\mathrm{Ca}_{\mathrm{I}}{ }^{2+}$ ions, on the $3\left(C_{3}\right)$ axis. $\mathrm{A}$ displacement of the $\mathrm{Ca}_{\mathrm{I}}^{2+}$ ions and a rotation, or a loss, of $\mathrm{PO}_{4}^{3-}$ ions in order to compensate the imbalance were observed. The substitution rate is $2 \mathrm{Sb}^{3+}$ for 3 adjacent $\mathrm{Ca}_{\mathrm{I}}^{2+}$ (DeBoer et al., 1991; Elliott, 1994).

The substitution of the $\mathrm{PO}_{4}{ }^{3-}$ ions by a substituent such as $\mathrm{XO}_{4}^{3-}(\mathrm{X}=\mathrm{V}, \mathrm{As}, \mathrm{Mn}, \mathrm{Cr} . .$.$) or \mathrm{CO}_{3}^{2-}$ (Elliott, 1994; Kreidler and Hummel, 1970; Perdikatsis, 1991) is called Type-B substitution. When the substituent is of the type $\mathrm{MO}_{4}^{3-}$, the substitution is partial or complete, with a substitution rate equal to $1: 1$. The $a$-axis and the $c$-axis parameters weakly increase, and we note a decrease of the $c / a$ rate. According to Kreidler, the radii of the atom $M$ must be between 0.29 and $0.6 \AA$ to conserve the $P 6_{3} / \mathrm{m}$ structure (Kreidler and Hummel, 1970). However, a $\mathrm{PO}_{4}^{3-}$ substitution often implies some distortions of the crystal structure, or a loss of the hexagonal symmetry. It is called pseudo-hexagonal structure because the main observed distortion is that of the $\mathrm{F}^{-}$ions (Kreidler and Hummel, 1970; Perdikatsis, 1991).

The substitution of $\mathrm{PO}_{4}{ }^{3-}$ ions by $\mathrm{CO}_{3}{ }^{2-}$ ones is generally accompanied by the loss of one $\mathrm{F}^{-}$ion and one or several $\mathrm{Ca}_{\mathrm{II}}{ }^{2+}$ ions, in order to compensate for the electronic disorder due to the substitution. The carbonated apatite structure is still uncertain. Some scientists, such as Perdikatsis (1991) think, according to their study on carbonated FAp minerals, that the space group is still $\mathrm{Pb}_{3} / \mathrm{m}$. However, it is difficult to prove this theory, and the substitution could imply a loss of symmetry, and then a change of the space group. Even the substitution way is uncertain: $\mathrm{CO}_{3}{ }^{2-}$ was first seen occupying a $\mathrm{PO}_{4}^{3-}$ site, with an $\mathrm{F}^{-}$ion or an $\mathrm{OH}^{-}$one occupying the site of the $4^{\text {th }} \mathrm{O}$. This theory was discarded, because it was thought that $\mathrm{CO}_{3}{ }^{2-}$ cannot occupy a site on the screw axis 6 , because of its steric space. Later, because of the P-O bonds, another study proposed that the $\mathrm{CO}_{3}{ }^{2-}$ ions are inclined on the $c$-axis, and occupy one of the tetrahedral $\mathrm{PO}_{4}^{3-}$ ion faces. Other substitution types were proposed, for example the substitution of $3 \mathrm{PO}_{4}^{3-}$ ions by $4 \mathrm{CO}_{3}{ }^{2-}$ (Elliott, 1994), but this substitution has not yet been fully proven.

\section{Conclusion}

Because of the presence of several ions in its formula, FAp is a very suitable host for various substituents. Moreover, FAp finds many applications in various areas and its biological properties are not the least important ones. This 
explains the large interest for this compound. The presence of FAp in human enamel, its use in treatments against dental caries or osteoporosis, and its dangerous (or lethal) effects when high doses are given, justify the interest in FAp. Several substitutions are possible, and their effects can have both good or bad consequences for the organism, and could even be lethal. The FAp structure seems to accept most substituents, despite size or valence differences. Only the $\mathrm{Ca}^{2+}$ substitution often implies some modifications of the crystal structure, when the substituent is smaller than $\mathrm{Ca}^{2+}$ ion. These modifications do not affect only the $\mathrm{Ca}^{2+}$ sites but also the other sites of the unit-cell. However, many questions remain, because not all the substitution forms are well-known, e.g., the $\mathrm{PO}_{4}^{3-}$ substitution. In the present study, we have carried out a graphical construction of all the atoms of the FAp unit-cell using the symmetry operators of the $P 6_{3} / m$ space group. The knowledge of such symmetries is not only useful for understanding the very structure of FAp but also for the detection of structural modifications induced by substitutions and hence for the understanding the behaviour of biological and synthetic calcium phosphate phases. We believe that such a description is useful to the biomaterials community.

\section{References}

Aoba T (1997) The effect of fluoride on apatite structure and growth. Crit Rev Oral Biol Med 8: 136-153.

Bale W F (1940) A comparative Roentgen-Ray diffraction study of several natural apatites and the apatite-like constituent of bone and teeth substance. Am J Roentgenol 43: 735-747.

DeBoer B G, Sakthivel A, Cagle JR, Young R A (1991) Determination of the Antimony Substitution Site in Calcium Fluorapatite from Powder X-ray Diffraction Data.. Acta Cryst B47: 683-692.

Elliott JC (1998) Structure and chemical properties of calcium phosphate. In : Bres E, Hardouin P (eds) Calcium Phosphate Materials - Fundamentals. Sauramps Medical, Montpellier, France. pp 25-66.

Elliott JC (1994) Structure and chemistry of the apatites and other calcium orthophosphates. Studies in inorganic chemistry. Elsevier, Amsterdam London New-York Tokyo.

Featherstone JD (1994) Fluoride, remineralization and root caries. Am J Dent 7: 271-274.

Fleet M E, Pan Y (1997) Site preference of rare earth elements in fluorapatite : Binary (LHREE+HREE)-substituted crystals. Am Miner 82 : 870-877.

Hann T (1993) International Tables of Crystallography, Brief Teaching Edition of Volume A, Space Group Symmetry. $3^{\text {rd }}$, revised and enlarged edition published for The International Union of Crystallography.Kluwer Academic Publishers, Dordrecht Boston London.

Hendricks S B, Jefferson M E, Mosley V M (1932) The crystal Structures of some natural and synthetic apatitelike substances. Z für Kristallographie 81: 352-369.

Hughes JM, Cameron M, Crowley KD (1991) Ordering of divalent cations in the apatite structure : Crystal structure refinements of natural $\mathrm{Mn}$ - and Sr-bearing apatite. Am Miner 76 : 1857-1862.
Hughes JM, Cameron M, Crowley KD (1990) Crystal structures of ternary apatites: Solid solution in the $\mathrm{Ca}_{5}\left(\mathrm{PO}_{4}\right)_{3} \mathrm{X}(\mathrm{X}=\mathrm{F}, \mathrm{OH}, \mathrm{Cl})$ system. Am Miner 75: 295304.

Hughes JM, Cameron M, Crowley KD (1989) Structural variations in natural $\mathrm{F}, \mathrm{OH}$, and $\mathrm{Cl}$ apatites. Am Miner 74: 870-876.

Ingram GS (1990) Chemical events during teeth dissolution. J Dent Res 69 Spec No: 581-586; discussion 634636.

Kay I, Young RA, Posner AS (1964) Crystal structure of hydroxyapatite. Nature 204: 1050-1052.

Kreidler ER, Hummel FA (1970) The crystal chemistry of apatite: structure fields of fluor- and chlorapatite. Am. Miner 55:170-184.

Mackie P E, Young R A (1974) Fluorine-Chlorine Interaction in Fluor-Chlorapatite. J Solid State Chem 11: 319 329.

Mackie P E, Young R A (1973) Location of Nd dopant in Fluorapatite, $\mathrm{Ca}_{5}\left(\mathrm{PO}_{4}\right)_{3} \mathrm{~F}$ :Nd. J Appl Cryst 6: 26-31.

Mehmel M (1932) Über die Struktur des Apatits (On the structure of apatite). Z für Kristallographie 81: 323-331.

Miyake M, Ishigaki K, Suzuki T (1986) Structure refinements of $\mathrm{Pb}^{2+}$ ion-exchanged apatites by $\mathrm{X}$-ray powder pattern-fitting. J Solid State Chem 61 : 230-235.

Naray-Szabo St (1930) The structure of apatite (CaF)Ca ${ }_{4}\left(\mathrm{PO}_{4}\right)_{3}$. Z für Kristallographie 75: 387-398.

Nounah A, Lacout JL (1992) Localization of cadmiumcontaining hydroxy- and fluorapatites. J Al Com. 188: 141146.

O'Shea DC, Baretlett ML, Young RA (1974) Compositional analysis of apatites with Laser Raman spectroscopy; (OH, F, Cl) apatites. Arch Oral Biol 19: 9951006.

Penel G, Leroy G, Rey C, Sombret B, Huvenne JP, Bres E (1997) Infrared and Raman microspectrometry study of fluor- fluor-hydroxy and hydroxyapatite powders. J Mater Sci : Mater in Med 8: 271-277.

Perdikatsis B (1991) X-ray powder diffraction study of francolite by the Rietveld method. Mat Sci Forum 79/82: 809-814.

Plouvier V (1997) Le Fluor: interets et conséquences Etude au niveau de deux sites régionaux (Fluorine: interests and consequences - A study at the level of two regional sites). Thèse de Chirurgien Dentiste (Thesis, Doctorate in Dental Surgery), Université Lille 2.

Radhakrisknan M (1964) Potential constants of some XY4 type molecules and ions. Z Physik Chem Neue Folge 41: 201-204.

Radhakrisknan M (1963) Urey-Bradley force field: Some XY4 type ions. Z Physik Chem Neue Folge 36: 227-231.

Schutte CJH, Bertie JE, Bunker PR, Hougen JT, Mills IM, Watson JKG, Winnewisser BP (1997) IUPAC Recommandations 1997. Notations and conventions in molecular spectroscopy. Pure \& Appl Chem 69: 1633-1657.

Sudarsanan K, Young RA (1978) Structural Interactions of F, $\mathrm{Cl}$ and $\mathrm{OH}$ in Apatites.Acta Cryst B34 : 1401-1407.

Sudarsanan K, Mackie PE, Young RA (1972) Comparison of synthetic and mineral fluoroapatite, $\mathrm{Ca}_{5}\left(\mathrm{PO}_{4}\right)_{3} \mathrm{~F}$, in crystallographic detail. Mat Res Bull 7: 1331-1338. 
Suitch PR, Lacout JL, Hewat A, Young RA (1985) The structural location and role of $\mathrm{Mn}^{2+}$ partially substituted for $\mathrm{Ca}^{2+}$ in fluorapatite. Acta Cryst B41: 173-179.

Triller M (1998) Le fluor, agent préventif de la maladie carieuse : mécanisme, sources, risques (Fluorine, a preventive agent against caries: mechanism, sources and risks). Arch Pédiatr 5 : 1149-1152.

Trombe JC (1973). Contribution à l'étude de la décomposition et de la réactivité de certaines apatites hydroxylées et carbonates (Contribution to the study of decomposition and reactivity of certain hydroxy- and carbonated apatites). Ann Chim Paris 14th series 8 : 251-269.

\section{Discussion with Reviewers}

D.B. Jones: "HA in the body slowly 'matures' by hydration. How is hydration affected by $\mathrm{F}$ in the molecule?

Authors: In HA, the oxygen atom of the hydroxyl group is below or above the $\mathrm{Ca}_{\mathrm{II}}{ }^{2+}$ triangles at $0.3 \AA$ of the $\mathrm{F}^{-}$position $(0 ; 0 ; 0.196)$ which causes a local disturbance [Hughes et al. 1989, Kay et al. 1964, Sudarsanan and Young 1978] with a possible transformation from the hexagonal structure (space group $P 6_{3} / m$ ) to a monoclinic one (space group $P 2 / b$ ). For steric reasons, this leaves room for indirect $\mathrm{H}_{2} \mathrm{O}$ substitution at the column. These disturbances can favour the hydratation of the apatite structure. In FAp, the fluoride ion is located at $\mathrm{Z}=1 / 4$, in the centre of the $\mathrm{Ca}_{\mathrm{II}}{ }^{2+}$ triangles, where it forms partially covalent $\mathrm{Ca}_{\mathrm{II}}-\mathrm{F}$ interactions. It is hence more difficult for a $\mathrm{F}^{-}$ion to be displaced in order to leave room for a $\mathrm{H}_{2} \mathrm{O}$ molecule.

D.B. Jones: Does $\mathrm{F}$ also form other compounds in bone than reacting with HA?

Authors: We cannot answer this question, and have no knowledge of other compounds formed in bone with fluoride, except for $\mathrm{F}, \mathrm{OH}-\mathrm{Ap}$ or $\mathrm{F}, \mathrm{CO}_{3}$-Ap.

S. Downes: Would the authors clearly indicate why the information generated using this technique could have value in the field of Biomaterials?

Authors: Both mineral phases of calcified tissues and synthetic calcium phosphate materials have a structure similar to that of FAp. Moreover, the physical and chemical properties of these apatites are related to their structure. This technique allows a better visualisation of the FAp structure and so favours a better understanding of the substitution mechanisms and of the physical and chemical properties of the apatites.

S. Downes: Would the authors like to strengthen their introduction by also indicating how HA can be substituted with groups such as carbonates? Can this technique be used to model these HA s?

Authors: This technique needs some precise data about the structure of the molecule we want to model. Except for a few cases, the structure of the carbonated apatites is not completely known. Therefore the representation of these apatites by this technique can, for the moment, only be a working hypothesis. 